\title{
THE EFFECT OF A FLIPPED CLASSROOM ON STUDENTS' ACHIEVEMENTS, ACADEMIC ENGAGEMENT AND SATISFACTION LEVELS
}

\author{
Dr. Tarik TALAN \\ ORCID: 0000-0002-5371-4520 \\ Vocational School of Technical Sciences \\ Kilis 7 Aralik University \\ Kilis, TURKEY \\ Dr. Sevinc GULSECEN \\ ORCID: 0000-0001-8537-7111 \\ Department of Informatics \\ Istanbul University \\ Istanbul, TURKEY
}

Received: 28/08/2018 Accepted: 18/02/2019

\begin{abstract}
In this study, a flipped classroom was compared with blended learning and face-to-face learning environments and the aim was to identify the effect of these learning environments on students' achievements, academic engagement and satisfaction levels. Based on this aim, one control and two experimental groups were formed. The students in Experiment-I learned the theoretical aspect of the course through the materials in the online learning environment which were prepared prior to the class study time in context with the "flipped classroom". The students in Experiment-II learned the theoretical aspect of the course in the classroom in accordance with the blended learning model and fulfilled active learning activities out of class study time. The students in the control group learned the theoretical aspect of the course in the classroom according to the current curriculum and conducted active learning activities at their homes. It was found that the scores for the students in the experimental groups with regard to academic achievement and engagement were higher than the scores for those in the control group and the differences between the groups were statistically significant. It was revealed that the students were also generally satisfied with the flipped classroom.
\end{abstract}

Keywords: Flipped classroom, blended learning, online learning, academic achievement, student participation, student satisfaction.

\section{INTRODUCTION}

Researchers and educators have searched alternative strategies and teaching methods to enable students effectively to participate in the teaching-learning process and to motivate them to study prior to class study time. The flipped classroom, which is a new educational trend is expected to be commonly implemented in tertiary education in the next few years and is regarded as one of these alternatives (Demiralay, 2014). This model, which is a new pedagogical approach, is a blended learning type where traditional face-toface teaching is inverted. This model provides a different teaching-learning process and effectively employs technology. Theoretical knowledge is taught to students by means of videos out-of-class study time and various activities and implementations are conducted in class study time in this model (Bergmann and Sams, 2012; Strayer, 2012). That is, in the flipped classroom, students are instructed at home and exposed to the assignment model at school (Demiralay, 2014).

The flipped classroom, which is an innovative learning model, is different from the traditional face-to-face learning method in the sense that students learn their lessons whenever and wherever they want before coming to school. Accordingly, teachers usually prepare their lesson contents through digital materials and 
enable their students to access these materials prior to lessons. In this way, students reach the related lesson contents with their teachers' instructions and the contents are conveyed to them before lessons. The issues which are ambiguous, problematic and cannot be sufficiently internalized are noted and posed to their teachers and peers through the electronic medium. By this means, the flipped classroom aims to address students' cognitive differences. When students come to the classroom, they will have more time to allocate to the activities and applications supporting the issue and will participate in the teaching-learning process more effectively and efficiently (Abeysekera and Dawson, 2014; Baker, 2000; Chen et al., 2014). In this way, students are provided with new opportunities for the subjects which are not learned in a classroom environment through flipped classroom technology (Kim, Park and Joo, 2014). Bergmann and Sams (2012), who are the pioneers of the flipped classroom, indicate that this method does not just mean video lessons, the main point in this method is the significant and interactive activities conducted in lessons. The issues emphasized in the definitions of this model are as follows: student-centered, supporting active learning, increasing class study time, providing a richer and more flexible learning environment through technological infrastructure, and being a component of blended learning.

The successful implementation of this model depends on knowing students' perceived value with regard to in class and out-of-class study time, their efforts in learning activities, relationships and interactions with their friends and teachers, their acquisitions and feelings stemming from training, involvement and encountered difficulties in these activities. A student's participation in lessons (academic engagements) involves the student's active involvement in educational activities, attending his/her school, fulfilling the assigned tasks/ homework and the eagerness which he/she displays under his/her teacher's instructions (Chapman, 2003; Skinner, Kinderman and Furrer, 2009). In addition to this definition, Kuh et al. (2011) defined student participation as an effective involvement in educational activities which are measurable outputs in and out of class including out-of-class activities.

A number of studies reveal that students' active participation in learning (asking questions, participation in classroom discussions and so forth) is one of the main determinants for a student's achievement (Furrer and Skinner, 2003; Kong, Wong and Lam, 2003; Pike and Kuh, 2005; Kuh, 2009; Errey and Wood, 2011; Harbour et al., 2015), whereas attending lessons at a low level can have negative effects on the learning process (Wang, Bergin and Bergin, 2014). Therefore, using active and collaborative learning methods in lessons, students' active participation in activities/applications, attaching importance to high order cognitive skills and enriching activities affect students' participation in lessons and achievements positively (Umbach and Wawrznyski, 2005). With its characteristics, the flipped classroom is thought to ensure students' participation and thereby develop their academic achievements and permanent learning.

It is envisaged that this study will make a contribution to more effectively using and evaluating the flipped classroom application which has a significant place in the integration of technology into education for the support of education. It was derived from the literature review that the flipped classroom is usually compared with the face-to-face learning method. This study not only compared the flipped classroom with blended learning and the traditional face-to-face learning method but also researched the effect of these learning environments on students' academic achievements and engagement. In this regard, it is expected to open new horizons about how the flipped classroom and blended learning, which have commonly been used in education thanks to technological improvements, will be implemented.

\section{The Purpose of the Study}

This study aimed to compare the flipped classroom, which is a new learning method, with blended learning and traditional face-to-face learning environments, and identify the effect of these learning environments on students' achievements, academic engagement and satisfaction levels. One control and two experimental groups were formed for this aim. Teaching was conducted through the flipped classroom in "Experiment-I", whereas it was implemented with the blended learning environment in "Experiment-II". The lessons were taught in the traditional face-to-face learning environment in the "Control Group". 
Within the framework of the general purpose of the research, the answers to the following questions were sought:

1. Is there a statistically significant difference between the students in Experiment-I, Experiment-II and the control group with regard to pre-test scores for their academic achievement?

2. Is there a statistically significant difference between the students in Experiment-I, Experiment-II and the control group with regard to pre-test and post-test scores for their academic achievement?

3. When the pre-test scores for the students in Experiment-I, Experiment-II and the control groups are controlled, is there a statistically significant difference with regard to post-test scores for their academic achievement?

4. Is there a statistically significant difference between the students in Experiment-I, Experiment-II and the control group with regard to their weekly quiz scores?

5. Is there a statistically significant difference between the students in Experiment-I, Experiment-II and the control groups with regard to their academic engagement?

6. Is there a significant relationship between students' "academic achievement scores" and "academic engagement" at the end of the implementation period?

7. What are the students' satisfaction levels for the learning environments at the end of the implementation period?

The independent variables of the research are learning approaches including the flipped classroom, blended learning and face-to-face learning, whereas the dependent variables are students' academic achievements, academic engagements and satisfaction levels.

\section{METHOD}

\section{Research Design}

In the research, quasi-experimental pre-test/post-test control group design was used. In the quasi-experimental technique, the participants are non-randomly assigned to groups. Groups are not formed or controlled for the experiment. Researchers make use of already existing groups (Ary et al., 2010; Creswell, 2012). When it is not possible to assign participants randomly to groups, the best alternative is to use a quasi-experimental design (Robson, 2011).

As the research was conducted in a state university and the subject areas were determined beforehand, it was not possible to assign the students randomly in Experiment-I, Experiment-II, and the control group. The students were separated into three groups, namely, Experiment-I, Experiment-II and the control group through non-randomized assignment before the implementation. All the students took an "academic achievement test" prior to the experimental treatment. At the end of the experimental one, the data, including their satisfaction levels and "academic achievement test" and "academic engagement" scales, were collected from the participants. The methods were implemented in each group to examine their effects on their academic achievements, academic engagements and satisfaction levels.

\section{Participants}

The current research was conducted in the "Computer-I" course in the Fall Semester 2017. The research study group consisted of students who study in three different subject areas which were randomly selected out of five different ones at a state university which is located in the Southeastern Region of Anatolia.

In the study, different teaching methods were implemented in the experimental and control groups. The science teaching program students studying in the Experiment-I group learned the theoretical aspect of the course through the materials prepared prior to their lesson hours in the context of the "flipped classroom" approach, and actively participated in the learning activities. The students studying in the Turkish teaching program in the Experiment-II group learned the theoretical aspects of their courses in their lessons in the context of the blended learning model and fulfilled active learning activities out of class study time. The primary school teaching program students in the control group learned the theoretical aspect of the course 
in the classroom according to the current curriculum and conducted active learning activities at their homes. One hundred and nineteen students (forty students in Experiment-I, thirty-nine students in Experiment-II, and forty students in the control group) participated in the study. The demographic characteristics of the participants are displayed in Table 1.

Table 1. Demographic Characteristics of the Participants

\begin{tabular}{|c|c|c|c|}
\hline Variable & Code & Frequencies (f) & Percent (\%) \\
\hline \multirow{2}{*}{ Gender } & Male & 31 & 26,1 \\
\hline & Female & 88 & 73,9 \\
\hline \multirow{3}{*}{ Groups } & Experiment-I & 40 & 33,6 \\
\hline & Experiment-II & 39 & 32,8 \\
\hline & Control & 40 & 33,6 \\
\hline \multirow{4}{*}{ Age } & Age $16-18$ & 15 & 12,6 \\
\hline & Age $19-21$ & 95 & 79,8 \\
\hline & Age $22-24$ & 7 & 5,9 \\
\hline & Age 25 and over & 2 & 1,7 \\
\hline Total & & 119 & 100,0 \\
\hline
\end{tabular}

As seen in Table 1, one hundred and nineteen participants were involved in the research. $26.1 \%(\mathrm{f}=31)$ and $73.9 \%$ ( $\mathrm{f}=88$ ) of the participants were male and female students, respectively. Forty of them were students in the Primary School Teaching program, forty in the Science Teaching program and thirty-nine in the Turkish Teaching program of the faculty. Concerning their age range, fifteen participants were 16-18, ninety-five were 19-21 and two participants were twenty-five and over.

The "flipped classroom" and "blended learning model" are the models which integrate technology into education. As the use of digital tools and the internet access are important in these models, the participants were asked to fill out a personal information form with regard to their access to the internet at the beginning of the process. Whether they had computers, smart phones and internet access was determined through this form. The information concerning the participants' access to technology in the control and experimental groups is displayed in Chart 1.

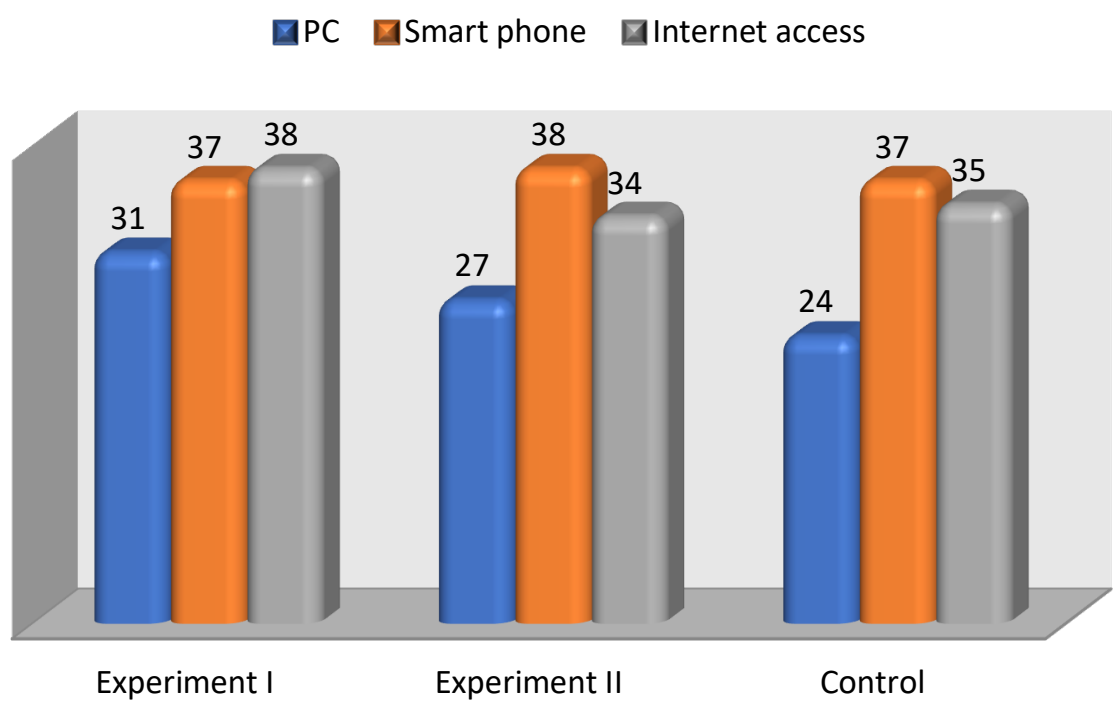

Chart 1. Information concerning the participants' access to technology 
When Chart 1 was examined, it was seen that the majority of the students had access to technology. $60 \%(\mathrm{~N}=24), 77.5 \%(\mathrm{~N}=31)$ and $69.2 \%(\mathrm{~N}=27)$ of the students in the control group, Experiment-I and Experiment-II, respectively, had their own personal computers at their homes or dormitories. It was revealed that three students in each control and in Experiment-I had their own smart phones, whereas only one student did not have a smart phone in Experiment-II. 87.5\% ( $\mathrm{N}=35), 95 \%(\mathrm{~N}=38)$ and $87.2 \%(\mathrm{~N}=34)$ of the students in the control, Experiment-I and Experiment-II, consecutively indicated access to the internet when answering the question dealing with their access to the internet. Those students who did not have access to the internet at their homes or dormitories, were given the chance to use computer labs on certain days to overcome the lack of technical tools issue. The information concerning the students' use of technology in the control and experimental groups is provided in Chart 2.

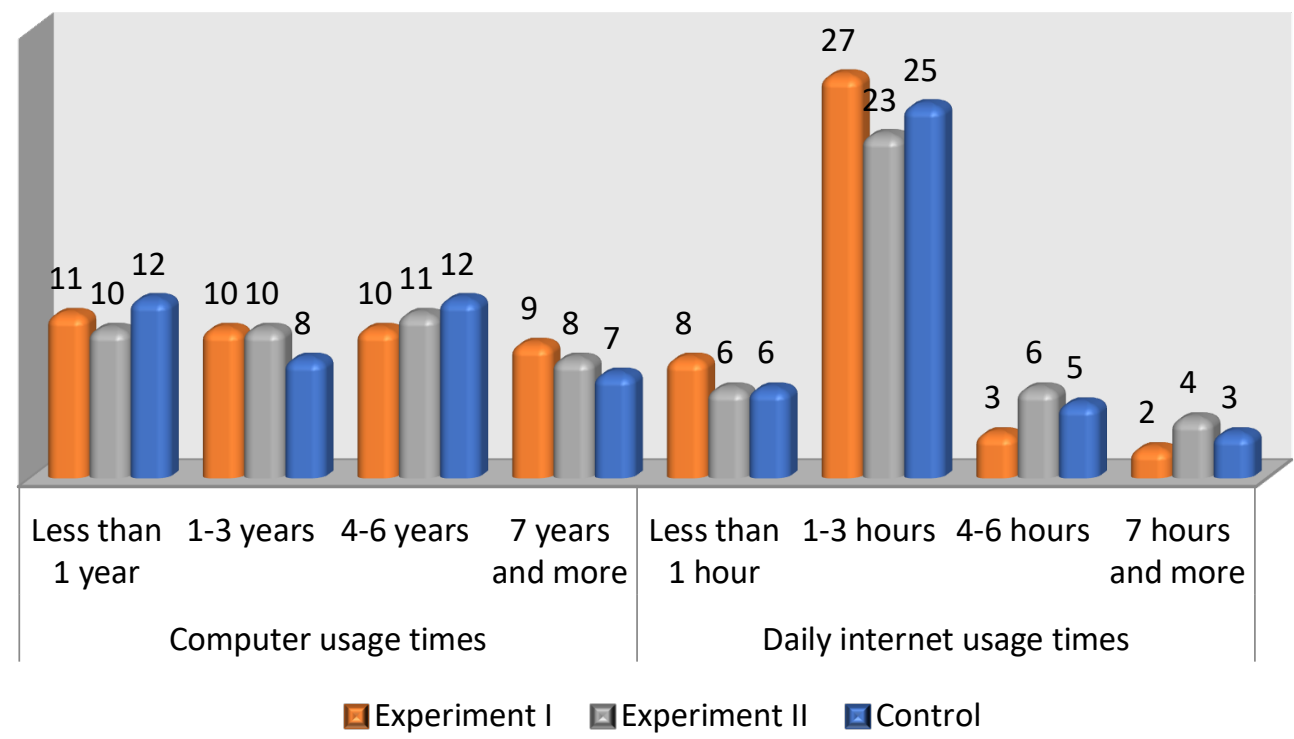

Chart 2. Information concerning the participants' use of technology

According to Chart 2, it can be seen that the participants' computer use of time in the control and experimental groups was similar, and they mostly used the internet for 1-3 hours in each group each day.

\section{Data Collection Instruments}

An achievement test was developed by the researcher and the experts to determine the students' knowledge level with regard to Computer-I course prior to the experimental treatment and to measure their achievements in the course in the post-experimental treatment. A table of specifications was prepared, taking into account the distribution of the questions for Microsoft Word and PowerPoint subjects in the context of the acquisitions for the related subjects in the Computer-I course to develop an achievement test. The table of specifications was designed according to the remember, understand and apply levels in Bloom's taxonomy. The other levels in Bloom's taxonomy were predominantly conducted in the classroom application and evaluation activities in the Computer-I course. Eight experts (three experts in curriculum development, one expert in assessment and evaluation, four experts in educational sciences) were consulted to ensure the content validity of the achievement test. Based on the experts' suggestions, the necessary changes were made to the test and, in the pilot study, it was applied beforehand to two hundred and thirty-seven students who took this course in the different programs of the Faculty of Education. A KR-20 (Kuder-Richardson) coefficient value was calculated for internal consistency in the academic achievement test following the pilot study implementation, and the coefficient value occurred as 0.805 . This value indicates that the internal consistency for the achievement test was "quite reliable" (Akbulut, 2010). It was found that the difficulty level of the test is 0.49 and its discrimination index was 0.45 . 
The "Academic Engagement" scale, whose reliability and validity analysis was conducted by Korucu (2013), was used to measure the students' academic engagement levels after the implementation process. It comprised five sub-components, namely "active learning", "engagement concerning the lesson and its requirements", "student and teacher interaction", "difficulties" and "feedback". The general reliability of the scale was found to be 0.728 . The reliability rates for the sub-components were as follows: "active learning" (0.708), "engagements concerning lesson and its requirements" (0.673), "student and teacher interaction" (0.701), "difficulties" (0.744) and "feedback" (0.716).

\section{METHODOLOGY}

The necessary institutional consents were obtained to conduct the research and collect the data before the experimental treatments. In addition, the system infrastructure was prepared and a planning process was initiated. After determining the pre-tests, materials and learning environment, seven-week (28 lesson hours) lesson plans, taking in the objectives, acquisitions and implementation activities, were prepared. An online learning environment, to be applied just in the experimental groups was designed and enabled the collection of detailed data with regard to the students' perceptions of the online learning environment. The determined subjects in Computer-I course were scheduled in modules in the online learning environment. At least one video, reading text (e-book), quiz and forum contents were prepared for each module to be used in Experiment-I (Figure 1). "Attaching a file to a submission" and forum contents were prepared for Experiment-II (Figure 2). The prepared materials were examined by the researcher and the course instructor separately.

\section{M.Word - File and Home}

Available from 26 September 2017, 12:00 PM

Video\# 1

e-book (reading text)\#1

Quiz\#1

Forum\#1

Figure 1. A sample for lesson contents created for the Experiment-I

\section{M.Word - File and Home}

Available from 3 October 2017, 12:00 PM

Activities (Homework) \#1

Ekteki "Etkinlik-1" uygulamasını bilgisayarınıza indirerek belirtilen tarihe kadar sisteme yükleyiniz. İyi çalışmalar...

Forum\#1

Figure 2. A sample for lesson contents created for the Experiment-II 
All of the students in the experimental groups were informed of the aims of the research, the lesson requirements and how they would be applied and their assignments in the learning environment one week prior to the research implementation. They were also informed of the characteristics of the online learning environment, the issues for the evaluation of the lesson, and the procedures of using the learning environment, and what to do when they encountered a technical problem.

A user account was created for each student in the experimental group and for the instructor in the online learning environment prior to the implementation of the study. Following the user procedures, the students were assigned to an experimental group and were ensured access to the groups' lesson materials and their defined rights in the forum and activity submission pages were arranged. The "Moodle Learning Management System Usage Guidebook" was shared with the students in each group. As the subjects were scheduled weekly in Moodle setting, students were asked to focus on that particular week's activities.

Prior to the main research implementation, the students in the experimental groups were involved in a oneweek pilot study to enable them to get familiar with the online learning environment, and in this way, it was ensured that they were prepared for the learning process. In the next stage, they participated in the main implementation. In the first week, the researcher attended the lesson with the instructor and communicated with the students after introducing himself. After the control and experimental groups were determined, the personal information form was administered, and the academic achievement tests were conducted prior to the implementation stage. The schematic flowchart of the implementation process is displayed below:

Apart from the Moodle setting, WhatsApp mobile message application as an instant communication tool was used with the students in the experimental group. A group was formed in WhatsApp for this research and the students communicated with the researcher, instructor and their friends through this application. Technical support was provided to the group by the researcher via WhatsApp any problems encountered in the online learning environment. Short message service (SMS) was also used as an instant communication for the students who do not use this application.

During the implementation process, seven assignments were given. Before and after the implementation process, the study was completed in ten weeks: two weeks for the application of the data collection instruments and informing the students of the study (one week for the pre-test and one week for the posttest), one week for conducting the quiz. The training activities were conducted with the students in the control and experimental groups in the same academic session by the same instructor. This research did not take into account those students as the participants who did not regularly attend the lessons and the studies in the research, did not take exams or had negative effects on the research implementation or did not use the materials in the online learning environment. There are significant differences in the control and experimental groups with regard to being instructed and assigned homework. The information concerning the conditions of the groups being assigned is provided below:

\section{Experimental Group I}

The students in the Experiment-I learned the theoretical aspect of their lesson by getting a variety of lesson materials including reading texts, video lecturing developed in the "flipped classroom" approach in Moodle setting through the tools which have internet access before their lesson. As the students' individual learning and learning pace are important in this group, they can track their lesson contents according to their learning pace whenever and wherever they need. After learning the theoretical knowledge of the lesson, they took quizzes in the Moodle setting. The feedback items for the quizzes were not provided in the Moodle setting. They were solved in the classroom by asking questions. They also wrote their ideas concerning the lesson and discussed the ambiguous issues online and in face-to-face communications in the forums. In this way, each student reviewed the lessons by sharing their knowledge in the forums and the student-student and studentinstructor interaction and communication continued out-of-the class study time. 


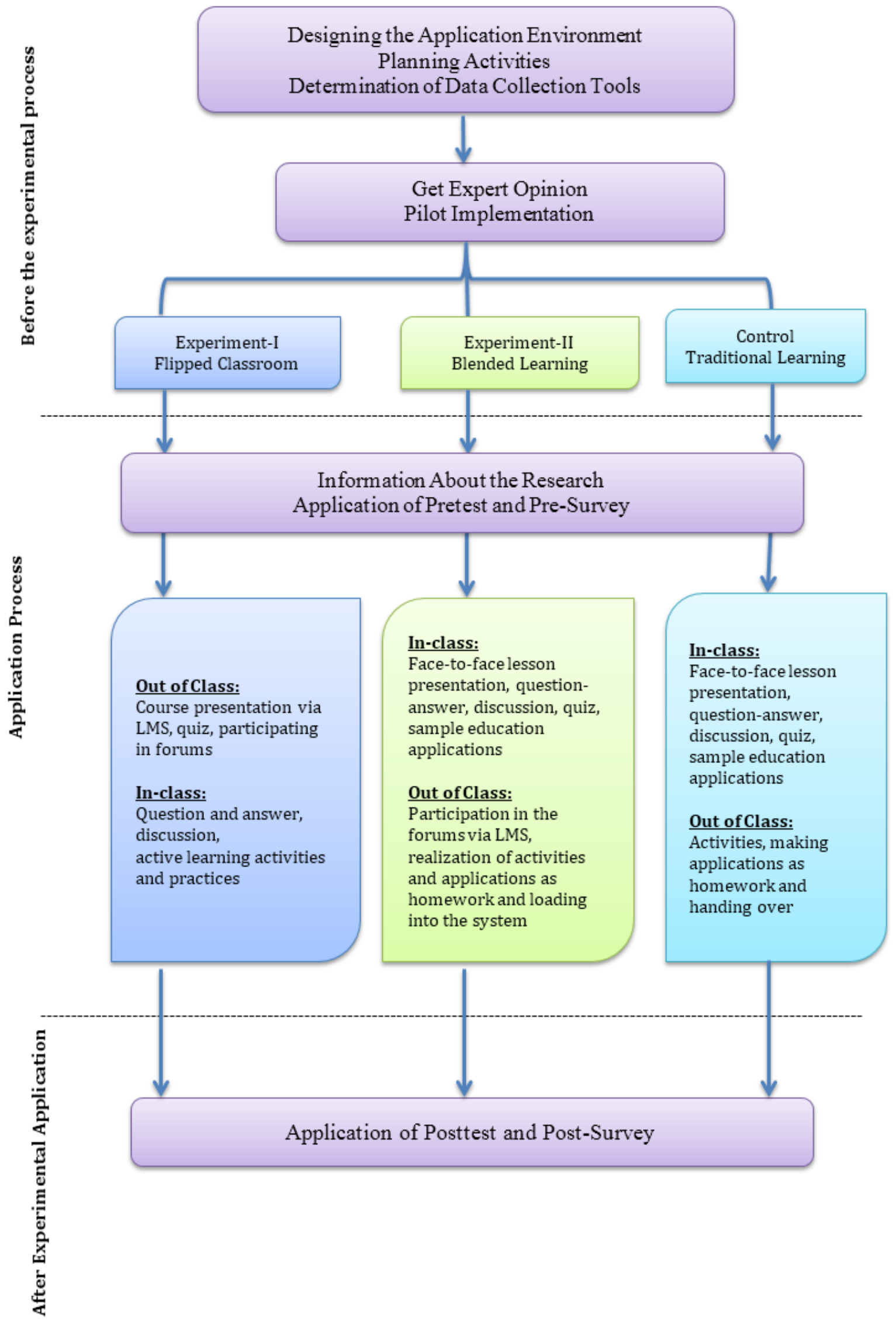

Figure 3. The schematic flow of the implementation process 
The students were asked to follow or read the lesson contents thoroughly and come to class prepared prior to their lessons. Those students who came to class unprepared were given a chance to track the lesson contents in the class before participating in the activities. Otherwise, students' attending the class unprepared would have a negative effect on fulfilling the method successfully.

The students in this group could ask their instructor the issues in the new materials they did not understand at the beginning of the lesson. In the next stage, they discussed the questions in the quizzes and in this way reviewed the subjects once more through these quizzes and it was identified whether there were problematic issues. When it was needed, the instructor made a mini presentation. The students dealt with the issues they could not grasp or misunderstood by discussing them with each other. The instructor almost did not need to interfere in dealing with these issues. In the remaining time, individuals or groups conducted the prepared activities for higher order learning including all the learned issues together and under the guidance of their instructor. As it is necessary to arrange time management in the flipped classroom, attention was paid to fulfill the activities in the classroom and not to assign them as homework. At the end of the activities, the issues which were not thoroughly learned were revised and were summarized by the instructor.

The course materials prepared by the researcher and instructor were published in Moodle setting one week prior to each lesson hour and the publication of these materials was announced in the groups created in the WhatsApp mobile application. The researcher checked every student's system records in Moodle to make sure that the students had watched the video lessons.

Based on the suggestions derived from the literature review, attention was paid to the length of the video lessons, which were to be between 10 and 25 minutes to increase the success of the implementation and to enable the students to watch them. The feedback items obtained from the students indicated that they sometimes needed much more time to study by themselves before class. The total length of the study materials before class was considered not to exceed 60 minutes as suggested. In this way, it is thought that the materials prepared before class do not place an excessive burden on students.

Although it was assumed that the students constantly accessed the online materials, the weekly course materials (e-book) could be downloaded and printed. The planned design for the flipped classroom was as follows:

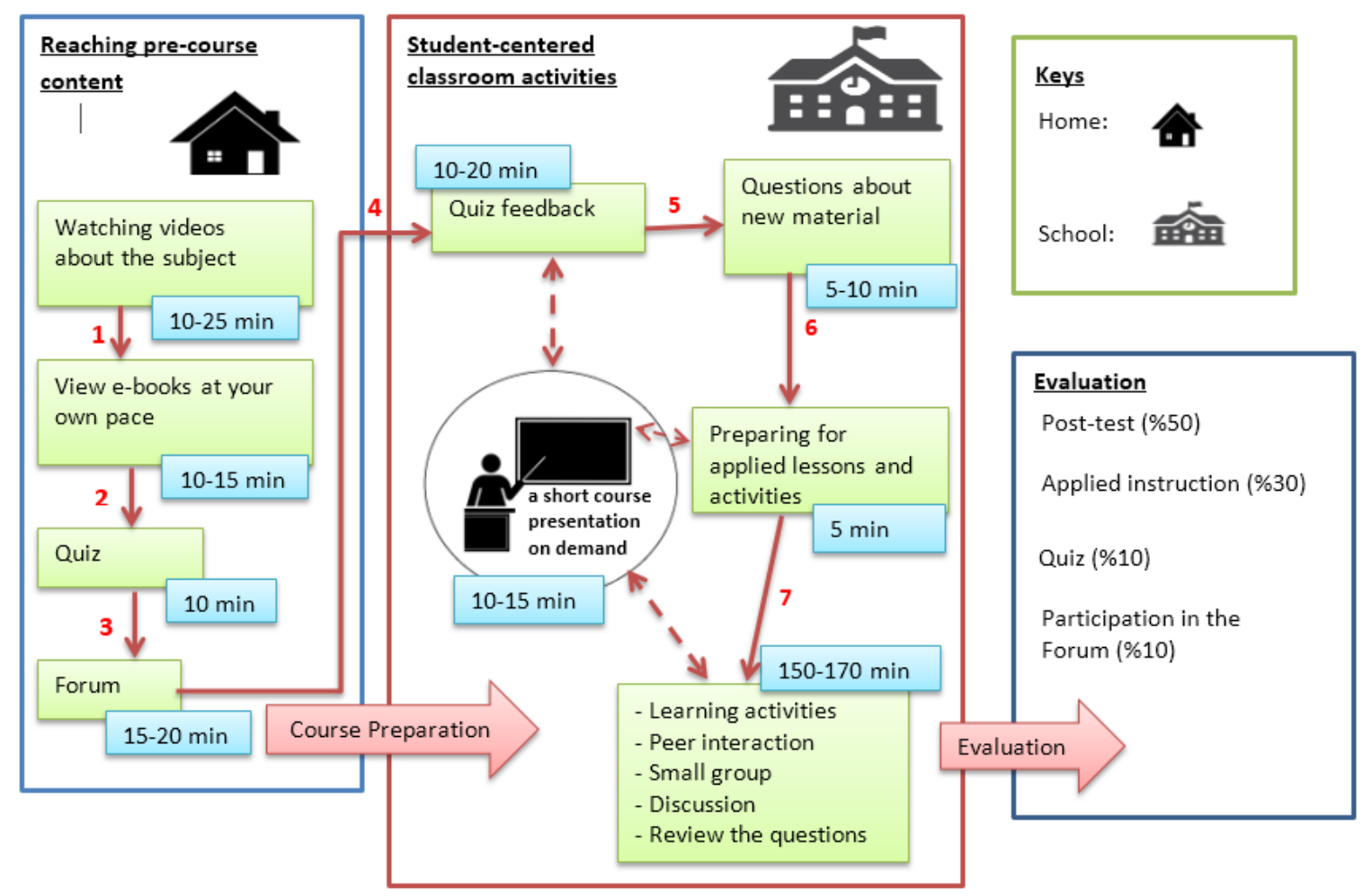

Figure 4. Flipped Classroom Design 


\section{Experimental Group II}

The students in this group learned the theoretical aspect of the course in classroom and conducted the activities involving learning strategies out of class study time in accordance with the "blended learning model".

The subjects were presented to the students by the instructor based on the principle of small steps in class and making no preparation before class. Direct instruction, presentation and question and answer methods were used to present the subjects. Following the presentations of the subjects, the quiz was conducted and the feedback for the questions was provided. The students' questions were answered and the subjects which were not grasped or misunderstood were corrected. After learning the theoretical lessons, in the remaining time reinforcing and practice training activities were conducted in the computer lab to build the infrastructure for the related course content and to make the issues more distinctive and long-lasting in the students' minds. At the end of every lesson, the points which were not learned were revised and the subjects were summarized by the instructor.

The activities which were prepared for higher order learning at the end of the lesson hour, were published in Moodle setting and these activities were announced in the group created in the WhatsApp mobile application.

The students were asked to load the materials they prepared to the system through the Moodle setting. There was a "Submission" button for the students to send their activities. The students in the experiment-II did the activities as homework, which were conducted in the classroom by the students in Experiment-I, and submitted these activities to their instructor via this button. In the forum pages, they were asked to exchange knowledge, pose questions on the issues they did not understand and contact their instructor. Also, in these pages, the homework was evaluated, feedback was provided and the errors were corrected.

\section{Control Group}

The students in the control group were asked to listen to the lessons in the classroom in accordance with the traditional face-to-face teaching method and conduct the activities involving the learning strategies for the subjects at home.

At the beginning of the lesson, the instructor provided the feedback for the activities conducted in the previous week and corrected the errors. The subject was presented by the instructor without any preparation for the students prior to the lesson. In the next stage, a quiz was conducted and its questions were answered. In the remaining time, reinforcing and practice training activities were conducted in the computer lab to build the basis for the related course content. At the end of each lesson, the points which were not learned were revised and the subject was summarized by the instructor.

The activities which were prepared for higher-order learning were used by means of printed copies out-ofclass study time. These activities were submitted in the classroom through flash memory (Universal Serial Bus (USB)) at the end of the one-week period. Those students who did not submit their activities on time or had inadequacies in their activities, were warned and asked to fulfil their duty. The feedback for their activities was regularly provided by the instructor and the researcher. The students were helped to understand the points with which they had difficulties.

\section{Data Analysis}

Parametric tests were used to analyze the data derived from the research. The normal distribution of the scales, the interval and ratio of the data and the homogeneity of the group variances were employed in these tests. The Kolmogorov Smirnov test was implemented to find out whether the data was normally distributed and it was revealed that it had a normal distribution. The Levene test was conducted to identify whether the variances of the data obtained from the control and experimental groups were homogeneous. After the variances were determined to be homogenous, the parametric tests were to be used. In this regard, the following tests were used: 
1. One-way ANOVA was used to identify whether there was a significant difference in the pre-test achievement scores conducted on the control and experimental groups.

2. A Paired Samples T-test was used to compare the pre-test and post-test achievement scores in Experiment-I, Experiment-II and the control groups.

3. One-factor ANCOVA was used to identify whether the post-test achievement scores for the control and experimental groups differentiate when the pre-test achievement scores for the groups are controlled. Although there was not a significant difference in the pre-test achievement scores, ANCOVA was implemented on the post-test achievement scores to remove the effect of the differences in the means. The pre-test achievement scores were used as a covariate. The following hypotheses of ANCOVA were fulfilled (Kalayci, 2010; Buyukozturk, 2011; Can, 2013):

- The groups were independent of each other.

- The groups' scores for the dependent variable showed normal distribution.

- The variances of the groups' scores for the dependent variable were homogeneous.

- There was a linear relationship between the dependent variable and the covariate.

- The regression coefficient of the inter-groups was equal.

4. One-Way ANOVA was used to identify whether the participants' scores derived from the quizzes show significant differences according to the instruction methods.

5. One-Way ANOVA was used to identify whether there was a significant difference in the students' academic engagement in the control and experimental groups.

6. The Pearson correlation coefficient was used to investigate whether there was a significant relationship between the students' "academic achievement scores" and "academic engagement" in the control and experimental groups.

7. Frequency and percentages were used to analyze the data with regard to the students' satisfaction in the control and experimental groups.

\section{FINDINGS}

This part focuses on the findings obtained from the pre-test and post-test achievement scores of the students in the control and experimental groups with regard to their academic engagement and satisfaction levels in the Computer-I course.

\section{The Findings with regard to the Academic Achievement Test in the Computer Course}

The interpretations of the data with regard to the pre-test and post-test academic achievement scores in the Computer-I course for the students in the control and Experiment-I and Experiment-II groups are provided in Tables 2-12.

\section{Comparison of the Pre-Test Achievement Scores for the Control and Experimental Groups}

Table 2. Descriptive statistics of the pre-test achievement scores for the students in the control and experimental groups

\begin{tabular}{llll}
\hline Groups & $\mathrm{N}$ & Mean & Sd \\
\hline Experiment-I & 40 & 16.40 & 5.27 \\
Experiment-II & 39 & 17.10 & 4.63 \\
Control & 40 & 15.45 & 4.95 \\
\hline
\end{tabular}


Table 2 indicates the students' means derived from the pre-test achievement tests conducted in Experiment-I $(M=16.40)$, Experiment-II $(M=17.10)$ and the control groups $(M=15.45)$. One-way ANOVA was implemented to identify whether there was a significant difference in the pre-test achievement scores prior to the implementation research. The homogeneity of the group variances had been tested before ANOVA analysis was conducted. The homogeneity of the variances with regard to the pre-test achievement scores was analyzed through a Levene test. The result of the test revealed that the variances are homogeneous $[\mathrm{F}=0.971$, $\mathrm{p}>0.05]$. As a result of the analysis, it was understood that the hypotheses of ANOVA were met and upon fulfilling the conditions for the ANOVA hypotheses an ANOVA analysis was conducted.

Table 3. The results of One-way ANOVA with regard to the pre-test achievement scores for the students in the control and experimental groups

\begin{tabular}{lrcrcc}
\hline Source of Variation & Sum of squares & df & Mean square & F & $\mathrm{p}$ \\
\hline Between the groups & 54.406 & 2 & 27.203 & 1.107 & 0.334 \\
Within the groups & 2851.090 & 116 & 24.578 & & \\
Total & 2905.496 & 118 & & & \\
\hline
\end{tabular}

According to the data in Table 3, the students' means obtained from the pre-test achievement scores in the control and Experiment-I and Experiment-II groups do not make a statistically significant difference $\left[\mathrm{F}_{(2}\right.$. $\left.{ }_{116)}=1.107 ; \mathrm{p}>.05\right]$. In other words, it can be stated that the students in these research groups were equal to each other prior to the implementation research.

Comparison of the pre-test and post-test achievement scores for the control and experimental groups

In-group comparisons were made to reveal whether there was a significant difference between the pre-test and post-test achievement scores for the students in the control, Experiment-I and Experiment-II groups. The results of the Paired Samples t-test are displayed in Table 4.

Table 4. The results of T-tests for the means of the pre-test and post-test achievements

\begin{tabular}{|c|c|c|c|c|c|c|c|}
\hline Groups & Test & $\mathbf{N}$ & Mean & Sd & df & $\mathbf{t}$ & $\mathbf{p}$ \\
\hline \multirow{2}{*}{ Experiment-I } & Pre & 40 & 16.40 & 5.27 & \multirow{2}{*}{39} & \multirow{2}{*}{-17.851} & \multirow{2}{*}{.000} \\
\hline & Post & 40 & 33.95 & 4.65 & & & \\
\hline \multirow{2}{*}{ Experiment-II } & Pre & 39 & 17.10 & 4.63 & \multirow{2}{*}{38} & \multirow{2}{*}{-14.846} & \multirow{2}{*}{.000} \\
\hline & Post & 39 & 33.59 & 5.60 & & & \\
\hline \multirow{2}{*}{ Control } & Pre & 40 & 15.45 & 4.95 & \multirow{2}{*}{39} & \multirow{2}{*}{-11.364} & \multirow{2}{*}{.000} \\
\hline & Post & 40 & 30.45 & 5.94 & & & \\
\hline
\end{tabular}

When Table 4 was examined, it was seen that there was a significant difference in favor of the post-test achievement scores among all the groups' pre-test and post-test ones $\left[\mathrm{t}_{\text {experiment-I }}(39)=-17.851, \mathrm{t}\right.$ experiment-II $(38)=$ $\left.-14.846, \mathrm{t}_{\text {control }}(39)=-11.364 ; \mathrm{p}<.05\right]$. Based on this result, it can be deduced that the instruction methods applied in all the groups have a positive effect on academic achievement. It was also seen that there was a 17.55 score increase in the academic achievement in favor of Experimental group-I, 16.49 score increase in Experimental group-II and 15 score increase in the control group. The differences in these groups could stem from the applied instruction methods. This finding can be interpreted that the flipped classroom is effective at increasing the students' academic achievements.

\section{The Suggested Homogeneity Tests to Conduct Covariance Analysis}

The following treatments were conducted to examine the hypotheses which are necessary to employ covariance analysis (ANCOVA): 
- The first hypothesis to be fulfilled in the groups was that observations should be made randomly and independently. This hypothesis did not require a statistical treatment and it dealt completely with the researchers' design and meticulousness in data collection and the fulfilment of this hypothesis was generally accepted by researchers (Mertler and Vannatta, 2002). To realize this hypothesis, the tests were conducted in the same setting at the same time. The data collection processes were carefully conducted through the observations made by the instructor and researcher Therefore, it can be stated that the students were minimally affected by each other and this hypothesis was realized. As this hypothesis was accepted for all the analyses, it was not mentioned again in the findings part.

- A Kolmogorov Smirnov test analysis was conducted to test the normal distribution of the achievement test scores. The results of the Kolmogorov Smirnov test analysis are displayed in Table 5. According to the data in Table 5, the groups' test scores show normal distribution.

Table 5. The results of the Kolmogorov Smirnov test analysis for the control and experimental groups

\begin{tabular}{llclc}
\hline Groups & Test & Statistics & Sd & P \\
\hline Experiment-I & Pre & 0.129 & 40 & 0.124 \\
& Post & 0.133 & 40 & 0.105 \\
\hline Experiment-II & Pre & 0.120 & 39 & 0.171 \\
& Post & 0.125 & 39 & 0.130 \\
\hline Control & Pre & 0.114 & 40 & 0.193 \\
& Post & 0.079 & 40 & 0.200 \\
\hline
\end{tabular}

- For ANCOVA analysis, the Levene test was employed to test the homogeneity of the variances and this was accepted when the "p" value was higher than $0.05[\mathrm{~F}=2.047, \mathrm{p}=0.134]$.

- For ANCOVA analysis, regression analysis was conducted to test whether there was a linear relationship between the dependent variable and the covariate. The results are indicated in Table 6.

Table 6. The relationship between the dependent variable and covariate

\begin{tabular}{llllc}
\hline Groups & Variables & N & R & P \\
\hline Experiment-I & PreXPost & 40 & 0.69 & 0.000 \\
Experiment-II & PreXPost & 39 & 0.52 & 0.001 \\
Control & PreXPost & 40 & 0.62 & 0.000 \\
\hline
\end{tabular}

When the analysis results in Table 6 were examined, it was seen that there was a statistically significant difference between the pre-test and post-test achievement scores for all the groups $(\mathrm{p}<.05)$.

- The hypothesis of the regression linear equation was fulfilled testing whether X pre-test had a significant effect on the post-test through the Custom Model (Buyukozturk, 2011).

Table 7. Group X pre-test results

\begin{tabular}{llcc}
\hline Dependent Variable & Covariate & F & p \\
\hline Total Post & Total Pre & 1.489 & $.230^{*}$ \\
\hline
\end{tabular}

When Table 7 was examined, it was seen that the effect of the group X pre-test on the post-test achievement scores for the students in the control and experimental groups was not significant $\left[\mathrm{F}_{(2.113)}=1.489, \mathrm{p}>.05\right]$. This finding indicates that the calculated regression linear equations with regard to the post-test achievement scores for the students in the control and experimental groups were homogeneous in terms of their pre-test achievement scores. 
The groups, being independent of each other, the normal distribution of the pre-test and post-test achievement scores, homogeneous variances, the linear relationship between the dependent variable and the covariate, homogeneous regression linear equations in the groups demonstrated that the necessary hypotheses for ANCOVA analysis were realized.

\section{Comparison of the Post-Test Achievement Scores for the Control and Experimental Groups}

The arithmetic of the post-test achievement test, the corrected arithmetic of the post-test according to the means of the pre-test scores and standard deviation values are displayed in Table 8.

Table 8. Descriptive statistics of the post-test achievement scores for the students in the control and experimental groups

\begin{tabular}{lllcc}
\hline Groups & N & Mean & Corrected Mean & Sd \\
\hline Experiment-I & 40 & 33.95 & 33.92 & 4.652 \\
Experiment-II & 39 & 33.59 & 33.70 & 5.599 \\
Control & 40 & 30.45 & 30.72 & 5.940 \\
\hline
\end{tabular}

The means of the post-test achievement tests of the students in Experimental group-I $(M=33.95)$, Experimental group-II $(M=33.59)$ and the control group $(M=30.45)$ are shown in Table 8. When the groups' means in the pre-test academic achievement were controlled, it is seen that a major change did not occur in the post-test mean scores. The corrected post-test academic mean scores were calculated to be 33.92 for Experimental group-I, 33.70 for Experimental group-II and 30.72 for the control group. The results of the ANCOVA analysis with regard to the observed differences between the groups' corrected post-test academic achievement scores are provided in Table 9.

Table 9. The results of ANCOVA with regard to the post-test scores based on the corrected pre-test scores

\begin{tabular}{lrcrcc}
\hline Source of Variation & Sum of squares & df & Mean square & F & p \\
\hline Pre (Regression) & 3.819 & 1 & 3.819 & 0.129 & .129 \\
Groups (Post) & 283.732 & 2 & 141.866 & 4.788 & .010 \\
Error & 3407.417 & 115 & 29.630 & & \\
Total (Corrected) & 130606.000 & 119 & & & \\
\hline
\end{tabular}

As seen in Table 9, it was found that there were significant differences between the students' post-test achievement scores in the research groups when their pre-test achievement scores were controlled $\left[\mathrm{F}_{(2.115)}=\right.$ $4.788, \mathrm{p}<.05]$. In other words, there were differences between the flipped classroom, blended learning model and the traditional face-to-face learning methods to increase the students' academic achievement. The results of the Scheffe test, which was conducted to identify in which groups the differentiations occurred, are displayed in Table 10.

Table 10. The detailed variance results of the comparison for the students' post-test scores in the control and experimental groups

\begin{tabular}{llrrc}
\hline (I) Learning method & $(\mathrm{J})$ Learning method & $\mathbf{( I - J )}$ & Sd & p \\
\hline Experiment-I & Experiment-II & 0.386 & 1.229 & 1.000 \\
& Control & $3.465\left(^{*}\right)$ & 1.222 & 0.010 \\
\hline Experiment-II & Experiment-I & -0.386 & 1.229 & 1.000 \\
& Control & $3.079\left(^{*}\right)$ & 1.239 & 0.031 \\
\hline Control & Experiment-I & $-3.465\left(^{*}\right)$ & 1.222 & 0.010 \\
& Experiment-II & $-3.079\left(^{*}\right)$ & 1.239 & 0.031 \\
\hline
\end{tabular}


According to the results of the Scheffe test, which was conducted taking into account the groups' corrected mean scores, the academic achievement derived from the teaching-learning processes implemented in Experimental group-I (=33.923) and Experimental group-II $(=33.698)$ was significantly higher than the one in the control group $(=30.722)$. A significant difference did not occur between the students' academic achievements in Experimental group-I and Experimental group-II. Based on this finding, it can be deduced that the teaching-learning processes implemented in Experimental group-I and Experimental group-II are more effective for the Computer-I course compared with the processes implemented in the control group.

\section{Findings of the Weekly Quizzes}

The findings of the students' weekly quiz scores in the control and Experiment-I and Experiment-II groups are provided in Tables 11 and 12.

Table 11. Descriptive statistics of the weekly quiz scores for the students in the control and experimental groups

\begin{tabular}{lccc}
\hline Groups & N & Mean & Sd \\
\hline Experiment-I & 40 & 7.57 & 0.98 \\
Experiment-II & 39 & 7.88 & 0.74 \\
Control & 40 & 7.62 & 0.70 \\
\hline
\end{tabular}

When the weekly quiz scores for the students in the control and experimental groups are examined, it is seen that the students' means in Experiment-I and Experiment-II and the control groups turned out to be 7.57, 7.88 and 7.62, respectively. The standard deviations for the Experiment-I and Experiment-II and control groups happened to be $0.98,0.74$ and 0.70 , consecutively. One-way ANOVA was conducted to identify whether a significant difference occurred between the weekly quiz scores. Before the ANOVA treatment was implemented, the homogeneity of the variances was tested. A Levene test was used to analyze the homogeneity of the variances. As a result of the analysis, it was found that the variances for the weekly quiz scores are homogeneous $[\mathrm{F}=2.314, \mathrm{p}>.05]$. Based on this result, ANOVA was conducted.

Table 12. The results of One-way ANOVA with regard to the weekly quiz scores for the students in the control and experimental groups

\begin{tabular}{cccccc}
\hline Source of Variation & Sum of squares & df & Mean square & F & p \\
\hline Between groups & 2.148 & 2 & 1.074 & 1.607 & .205 \\
Within groups & 77.547 & 116 & 0.669 & & \\
Total & 79.696 & 118 & & & \\
\hline
\end{tabular}

When the data in Table 12 is examined, it can be seen that a significant difference did not occur in the weekly quiz scores for the students in the control and experimental groups $\left[\mathrm{F}_{(2.116)}=1.607 ; \mathrm{p}>.05\right]$.

\section{The Findings of the Academic Engagement Scale}

In this part, the interpretations of the findings with regard to the "academic engagement scale" are provided in Tables 13 and 18. 


\section{The Analysis Results of the Academic Engagement Scale}

The homogeneity of the group variances with regard to the academic engagement scale for the students in the control and experimental groups was checked through a Levene test and it was revealed that the variances are homogeneous $[\mathrm{F}=0.613, \mathrm{p}>0.05]$. One-way ANOVA was conducted to identify whether significant differences occurred in the academic engagement scale and its sub-dimensions. The results are provided below:

Table 13. The results of One-way ANOVA with regard to the academic engagement scale and its subdimensions for the students in the control and experimental groups

\begin{tabular}{|c|c|c|c|c|c|c|c|c|c|c|}
\hline Subscales & Groups & $\mathrm{N}$ & Mean & Sd & $\begin{array}{l}\text { Source of } \\
\text { Variation }\end{array}$ & $\begin{array}{l}\text { Sum of } \\
\text { squares }\end{array}$ & $d f$ & $\begin{array}{l}\text { Mean } \\
\text { square }\end{array}$ & $\mathrm{F}$ & $p$ \\
\hline \multirow{3}{*}{$\begin{array}{l}\text { Engagements } \\
\text { for the course } \\
\text { and its } \\
\text { requirements }\end{array}$} & Experiment-I & 40 & 24.40 & 3.37 & $\begin{array}{l}\text { Between the } \\
\text { groups }\end{array}$ & 35,85 & 2 & 17.893 & 1.519 & 0.223 \\
\hline & Experiment-II & 39 & 24.85 & 3.21 & $\begin{array}{l}\text { Within the } \\
\text { groups }\end{array}$ & 1366.652 & 116 & 11.781 & & \\
\hline & Control & 40 & 23.53 & 3.70 & Total & 1402.437 & 118 & & & \\
\hline \multirow{3}{*}{$\begin{array}{l}\text { Student } \\
\text { and teacher } \\
\text { interaction }\end{array}$} & Experiment-I & 40 & 16.08 & 3.73 & $\begin{array}{l}\text { Between the } \\
\text { groups }\end{array}$ & 369.445 & 2 & 184.722 & 10.622 & 0.000 \\
\hline & Experiment-II & 39 & 15.23 & 3.82 & $\begin{array}{l}\text { Within the } \\
\text { groups }\end{array}$ & 2009.698 & 116 & 17.325 & & \\
\hline & Control & 40 & 12.00 & 4.83 & Total & 2379.143 & 118 & & & \\
\hline \multirow[t]{3}{*}{ Feedback } & Experiment-I & 40 & 17.50 & 1.69 & $\begin{array}{l}\text { Between the } \\
\text { groups }\end{array}$ & 34.465 & 2 & 17.232 & 3.476 & 0.034 \\
\hline & Experiment-II & 39 & 17.95 & 2.34 & $\begin{array}{l}\text { Within the } \\
\text { groups }\end{array}$ & 574.997 & 116 & 4.957 & & \\
\hline & Control & 40 & 16.65 & 2.56 & Total & 609.462 & 118 & & & \\
\hline \multirow[t]{3}{*}{ Active learning } & Experiment-I & 40 & 26.18 & 2.34 & $\begin{array}{l}\text { Between the } \\
\text { groups }\end{array}$ & 5.254 & 2 & 2.627 & .399 & 0.672 \\
\hline & Experiment-II & 39 & 26.49 & 2.52 & $\begin{array}{l}\text { Within the } \\
\text { groups }\end{array}$ & 764.494 & 116 & 6.590 & & \\
\hline & Control & 40 & 25.98 & 2.82 & Total & 769.748 & 118 & & & \\
\hline \multirow[t]{3}{*}{$\begin{array}{l}\text { Difficulties } \\
\text { dimension }\end{array}$} & Experiment-I & 40 & 10.28 & 3.11 & $\begin{array}{l}\text { Between the } \\
\text { groups }\end{array}$ & 34.151 & 2 & 17.076 & 2.065 & 0.131 \\
\hline & Experiment-II & 39 & 11.59 & 2.93 & $\begin{array}{l}\text { Within the } \\
\text { groups }\end{array}$ & 959.311 & 116 & 8.270 & & \\
\hline & Control & 40 & 10.95 & 2.57 & Total & 993.462 & 118 & & & \\
\hline \multirow[t]{3}{*}{ GENERAL } & Experiment-I & 40 & 94.43 & 9.16 & $\begin{array}{l}\text { Between the } \\
\text { groups }\end{array}$ & 1060.968 & 2 & 530.484 & 6.364 & 0.002 \\
\hline & Experiment-II & 39 & 96.10 & 8.38 & $\begin{array}{l}\text { Within the } \\
\text { groups }\end{array}$ & 9668.965 & 116 & 83.353 & & \\
\hline & Control & 40 & 89.10 & 9.77 & Total & 10729.933 & 118 & & & \\
\hline
\end{tabular}

\section{i. Engagement in the course}

Where the students' "engagement in the course" was concerned, it was seen that the students' means in Experiment-I, Experiment-II and in the control group were 24.40, 24.85 and 23.53 respectively. The standard deviations for Experiment-I, Experiment-II and the control group were 3.37, 3.21 and 3.70 consecutively. When the data were taken into account, no significant difference was identified in the students' course engagement levels $\left[\mathrm{F}_{(2,116)}=1.519 ; \mathrm{p}>.05\right]$. 


\section{ii. Student and teacher interaction}

When the students' "student and teacher interaction" was examined, it was seen that the students' mean scores in Experiment-I and Experiment-II and in the control groups were 16.08, 15.23 and 12.00 respectively. The standard deviations for the Experiment-I, Experiment-II and control groups were $3.73,3.82$ and 4.83 consecutively. The significant differences were found in the students' "student and teacher interaction" dimension $\left[\mathrm{F}_{(2.116)}=10.622, \mathrm{p}<.05\right]$. A Scheffe test was employed to find out in which groups the significant differences occurred. The results of the test are indicated in Table 14.

Table 14. The detailed variance analysis results with regard to the comparison for the students' "student and teacher interaction" in the control and experimental groups

\begin{tabular}{llrcc}
\hline (I) Learning method & (J) Learning method & (I-J) & Sd & p \\
\hline \multirow{2}{*}{ Experiment-I } & Experiment-II & 0.84423 & 0.93667 & 0.667 \\
& Control & $4.07500^{*}$ & 0.93073 & 0.000 \\
\hline \multirow{2}{*}{ Experiment-II } & Experiment-I & -0.84423 & 0.93667 & 0.667 \\
& Control & $3.23077^{*}$ & 0.93667 & 0.003 \\
\hline \multirow{2}{*}{ Control } & Experiment-I & $-4.07500^{*}$ & 0.93073 & 0.000 \\
& Experiment-II & $-3.23077^{*}$ & 0.93667 & 0.003 \\
\hline
\end{tabular}

According to the results of the Scheffe test for the groups' "student and teacher interaction" dimension, it was revealed that there was a statistically significant difference in favor of the Experimental group-I between the Experimental group-I and the control group and a significant difference in favor of the Experimental group-II between the Experimental group-II and the control group [p<.05]. Based on this finding, it can be deduced that the students in Experimental group-I $(=16,08)$ and Experimental group-II $(=15,23)$ were more involved in academic interaction with regard to "student and teacher interaction" compared with the students in the control group $(=12,00)$. Significant differences did not happen in the other sub-groups of this dimension $[\mathrm{p}>$.05].

\section{iii. Feedback}

Where the students' "feedback" was concerned, it was seen that the students' mean scores in Experimental group-I, Experimental group-II and in the control group were 17.50, 17.95 and 16.65, respectively. The standard deviations for Experimental group-I, Experimental group-II and the control were 1.69, 2.35 and 2.56, consecutively. One-way ANOVA was applied to reveal whether a significant difference occurred in "feedback". Table 13 indicates that there were significant differences between the students in the control and experimental groups with regard to the "feedback" dimension $\left[\mathrm{F}_{(2,}\right.$ $\left.{ }_{116}=3.476, \mathrm{p}<.05\right]$. A Scheffe test was employed to find out in which groups the significant differences occurred. The results of the test are indicated in Table 15.

Table 15. The detailed variance analysis results with regard to the comparison for the students' "feedback" in the control and experimental groups

\begin{tabular}{llrcc}
\hline (I) Learning method & (J) Learning method & (I-J) & Sd & p \\
\hline \multirow{2}{*}{ Experiment-I } & Experiment-II & -.44872 & .50102 & .671 \\
& Control & .85000 & .49784 & .237 \\
\hline \multirow{2}{*}{ Experiment-II } & Experiment-I & .44872 & .50102 & .671 \\
& Control & $1.29872^{*}$ & .50102 & .038 \\
\hline \multirow{2}{*}{ Control } & Experiment-I & -.85000 & .49784 & .237 \\
& Experiment-II & $-1.29872^{*}$ & .50102 & .038 \\
\hline
\end{tabular}


According to the results of the Scheffe test for the groups' "feedback" dimension, it was indicated that there was a statistically significant difference in favor of Experimental group-II between the Experimental group-II and the control group [p<.05]. In the light of this finding, it can interpreted that the students in Experimental group-I $(=17.95)$ deal with providing "feedback" in the academic sense compared with the ones in the control group $(=16.65)$. Significant differences did not happen in the other sub-groups in this dimension $[\mathrm{p}>.05]$.

\section{iv. Active learning}

Where the students' "active learning" was concerned, it was revealed that the students' mean scores in the Experiment-I, Experiment-II and in the control groups were 26.18, 26.49 and 25.98, respectively. The standard deviations for Experiment-I, Experiment-II and the control were 2.34, 2.52 and 2.82, consecutively. One-way ANOVA was conducted to reveal whether a significant difference occurred in the "active learning" dimension. When the data in Table 13 are taken into account, it was seen that a significant difference did not appear in the students' "active learning dimension" in the control and experimental groups $\left[\mathrm{F}_{(2,116)}=0.399 ; \mathrm{p}>.05\right]$. This finding shows a parallel with the one in the "engagement in the course" dimension.

\section{v. Difficulties}

When the students' "difficulties dimension" was taken into account, it was seen that the students' mean scores in the Experiment-I, Experiment-II and in the control groups were 10.28, 11.59 and 10.95, respectively. The standard deviations for the Experiment-I, Experiment-II and control groups were $3.11,2.93$ and 2.57, consecutively. One-way ANOVA was conducted to reveal whether a significant difference occurred in the "difficulties" dimension. When the data in Table 1 were examined, it was seen that a significant difference did not appear in the students' "difficulties dimension" in the control and experimental groups $\left[\mathrm{F}_{(2.116)}=2.065 ; \mathrm{p}>.05\right]$. It can be deduced from this finding that the students in the control, Experiment-I and Experiment-II groups faced similar difficulties.

\section{General Academic Engagement Scale}

When the students' scores derived from the general "academic engagement" scale were examined, it was revealed that the students' mean scores in Experiment-I, Experiment-II and in the control groups were 94.43, 96.10 and 89.10, respectively. The standard deviations for Experiment-I, Experiment-II and the control groups were 9.16, 8.38 and 9.77, consecutively. One-way ANOVA was conducted to reveal whether a significant difference occurred in the students' "academic engagement". When examining the data in Table 13 , it was seen that a significant difference appeared in the students' academic engagement in the control and experimental groups $\left[\mathrm{F}_{(2.116)}=6.364, \mathrm{p}<.05\right]$. A Scheffe test was conducted to find out in which groups the significant differences occurred. The results of the test are indicated in Table 16.

Table 16. The detailed variance analysis results with regard to the comparison for the students' "academic engagements" in the control and experimental groups

\begin{tabular}{llrrc}
\hline (I) Learning method & (J) Learning method & (I-J) & Sd & p \\
\hline \multirow{2}{*}{ Experiment-I } & Experiment-II & -1.67756 & 2.05453 & .717 \\
& Control & $5.32500^{*}$ & 2.04148 & .037 \\
\hline \multirow{2}{*}{ Experiment-II } & Experiment -I & 1.67756 & 2.05453 & .717 \\
& Control & $7.00256^{*}$ & 2.05453 & .004 \\
\hline \multirow{2}{*}{ Control } & Experiment-I & $-5.32500^{*}$ & 2.04148 & .037 \\
& Experiment-II & $-7.00256^{*}$ & 2.05453 & .004 \\
\hline
\end{tabular}


According to the results of the Scheffe test for the groups' "academic engagement" scale, it was indicated that there was a statistically significant difference in favor of Experimental group-I between Experimental group-I and the control group and a significant difference in favor of Experimental group-II between Experimental group-II and the control group [p<.05]. This finding indicates that the students in Experimental group-I $(=94.43)$ and in Experimental group-II $(=96,10)$ were more involved in academic engagement than the ones in the control group $(=89.10)$. Significant differences did not happen in the other sub-groups of this dimension $[\mathrm{p}>.05]$.

\section{Descriptive Statistics for Academic Engagement}

Table 17 was created for the students in the control, Experimental -I and Experimental-II groups to compare their completed tasks during the implementation processes and their academic engagement periods with regard to the study time for the exams.

Table 17. The weekly study schedule for the control and experimental groups in the implementation processes

\begin{tabular}{|c|c|c|c|c|}
\hline Variables & Time & Experiment-I & Experiment-II & Control \\
\hline \multirow{6}{*}{$\begin{array}{l}\text { How much time did you spend each } \\
\text { week to complete the course task? }\end{array}$} & $0-15 \mathrm{~min}$ & 0 & 0 & 2 \\
\hline & $16-30 \mathrm{~min}$ & 11 & 2 & 2 \\
\hline & $31-45 \mathrm{~min}$ & 15 & 1 & 3 \\
\hline & $46-60 \mathrm{~min}$ & 10 & 7 & 2 \\
\hline & $61-90 \mathrm{~min}$ & 4 & 11 & 4 \\
\hline & $>90 \mathrm{~min}$ & 0 & 18 & 27 \\
\hline \multirow{5}{*}{$\begin{array}{l}\text { How much time did you spend on } \\
\text { weekly meetings with the instructor } \\
\text { to complete the course tasks? }\end{array}$} & 0 & 11 & 10 & 20 \\
\hline & $1-15 \min$ & 11 & 22 & 7 \\
\hline & $16-30 \mathrm{~min}$ & 6 & 4 & 5 \\
\hline & $31-45 \mathrm{~min}$ & 6 & 1 & 2 \\
\hline & $>45 \mathrm{~min}$ & 6 & 2 & 6 \\
\hline \multirow{7}{*}{$\begin{array}{l}\text { How much time did you spend } \\
\text { preparing for the course exam? }\end{array}$} & $0-15 \mathrm{~min}$ & 3 & 4 & 2 \\
\hline & $16-30 \mathrm{~min}$ & 6 & 3 & 2 \\
\hline & $31-45 \mathrm{~min}$ & 4 & 2 & 3 \\
\hline & $46-60 \min$ & 8 & 8 & 9 \\
\hline & $61-90 \mathrm{~min}$ & 6 & 3 & 4 \\
\hline & $91-120 \mathrm{~min}$ & 7 & 11 & 10 \\
\hline & $>120 \mathrm{~min}$ & 6 & 8 & 10 \\
\hline
\end{tabular}

The weekly study hours the students in the control, Experiment-I and Experiment-II groups spent in the implementation processes are displayed in Table $17.90 \%$ of the students in the flipped classroom $(\mathrm{N}=36)$, $26 \%$ of the students taught through the blended learning model $(\mathrm{N}=10)$ and $23 \%$ of the students taught through the traditional face-to-face learning method $(\mathrm{N}=9)$ spent less than 60 minutes per week to complete their course tasks. It was indicated that $74 \%$ of the students in the blended learning model $(\mathrm{N}=29)$ and $78 \%$ of the students in the traditional face-to-face model $(\mathrm{N}=31)$ spent more than 60 minutes per week to complete the tasks.

The students in the study were asked to indicate in their interview with their instructor how much time they spent in finishing the tasks per week. $28 \%$ of the students in the flipped classroom $(\mathrm{N}=11), 26 \%$ of the students in the blended learning $(\mathrm{N}=10)$ and $50 \%$ of the students in the traditional face-to-face learning method $(\mathrm{N}=20)$ did not have a talk with their instructor. It can be derived from this finding that the students in the traditional face-to-face learning method spent less time talking to their instructor in order to fulfil their tasks, compared with the others in the flipped classroom and blended learning models. 
The students in the control and experimental groups were also asked how much time they spent in preparation for their course exams. 53\% of the students in the flipped classroom $(\mathrm{N}=21), 44 \%$ of the students in the blended learning model $(\mathrm{N}=17)$ and $40 \%$ of the students in the traditional face-to-face learning method $(\mathrm{N}=16)$ indicated that they spent less than 60 minutes per week studying for the exams. Based on this finding, it can be interpreted that the periods the students in the different groups spent on study for their exams were almost the same and, in this sense, there is a consistency in the time allocated for preparation for the exam.

Table 18. The frequency of the students' communication with their group members and instructor

\begin{tabular}{|c|c|c|c|c|}
\hline Variables & Time & Experiment-I & Experiment-II & Control \\
\hline \multirow{4}{*}{$\begin{array}{l}\text { How many times per week did you } \\
\text { contact your instructor out-of-the class } \\
\text { study time? }\end{array}$} & 0 & 19 & 17 & 28 \\
\hline & 1-2 Times & 17 & 19 & 7 \\
\hline & 3-4 Times & 4 & 3 & 5 \\
\hline & 5 times and more & 0 & 0 & 0 \\
\hline \multirow{4}{*}{$\begin{array}{l}\text { How many times per week did you } \\
\text { contact your instructor during the } \\
\text { lesson? }\end{array}$} & 0 & 0 & 5 & 5 \\
\hline & 1-2 Times & 13 & 16 & 16 \\
\hline & 3-4 Times & 10 & 10 & 10 \\
\hline & 5 times and more & 17 & 8 & 9 \\
\hline \multirow{4}{*}{$\begin{array}{l}\text { How much time did you get to take the } \\
\text { opportunity to ask questions to your } \\
\text { classmates and study with them out-of- } \\
\text { the class study time? }\end{array}$} & 0 & 2 & 3 & 11 \\
\hline & 1-2 Times & 23 & 5 & 7 \\
\hline & 3-4 Times & 9 & 7 & 7 \\
\hline & 5 times and more & 6 & 24 & 15 \\
\hline \multirow{4}{*}{$\begin{array}{l}\text { How much time did you get to take the } \\
\text { opportunity to ask questions to your } \\
\text { classmates and study with them during } \\
\text { the lesson? }\end{array}$} & 0 & 2 & 4 & 1 \\
\hline & 1-2 Times & 5 & 12 & 7 \\
\hline & 3-4 Times & 16 & 3 & 15 \\
\hline & 5 times and more & 17 & 20 & 17 \\
\hline
\end{tabular}

When Table 18 is examined, 53\% of the students in the flipped classroom $(\mathrm{N}=21)$ and $56 \%$ of the students in the blended learning model $(\mathrm{N}=21)$ said that they made contact with their instructor at least once a week. $70 \%$ of the students in the traditional face-to-face learning method did not make any contact with their instructor. In addition, all of the students in the flipped classroom, $87 \%$ of the students in the blended learning model $(\mathrm{N}=34)$ and $88 \%$ of the students in the traditional face-to-face learning method $(\mathrm{N}=35)$ had a talk with their instructor in the lesson at least once.

$95 \%$ of the students in the flipped classroom $(\mathrm{N}=38), 92 \%$ of the students in the blended learning model $(\mathrm{N}=36)$ and $73 \%$ of the students in the traditional face-to-face learning method $(\mathrm{N}=29)$ stated that they had an opportunity to ask questions of their classmates and study with them at least once during out of class study time. $95 \%$ of the students in the flipped classroom (N=38), 90\% of the students in the blended learning model $(\mathrm{N}=35)$ and $99 \%$ of the students in the traditional face-to-face learning method $(\mathrm{N}=99)$ expressed that they had an opportunity to ask questions of their classmates and study with them at least once during the lesson.

\section{The Findings for the Students' Satisfaction Levels}

The students in the control and experimental groups were asked about their perceptions of the course and their answers are displayed in Table 19. 
Table 19. The frequency of the students' answers for the perceptions with regard to the course

\begin{tabular}{|c|c|c|c|c|}
\hline Variables & Values & Experiment-I & Experiment-II & Control \\
\hline \multirow{4}{*}{$\begin{array}{l}\text { How effective were the tasks } \\
\text { assigned in the lesson on } \\
\text { your learning? }\end{array}$} & Useful & 29 & 33 & 30 \\
\hline & Partially useful & 9 & 5 & 6 \\
\hline & Not useful & 1 & 1 & 1 \\
\hline & Indecisive & 1 & 0 & 3 \\
\hline \multirow{3}{*}{$\begin{array}{l}\text { Assigned tasks generally } \\
\text { given in the course; }\end{array}$} & Very easy & 5 & 1 & 3 \\
\hline & Moderately difficult & 34 & 30 & 28 \\
\hline & Very difficult & 1 & 8 & 9 \\
\hline \multirow[t]{4}{*}{$\begin{array}{l}\text { Do you believe this content } \\
\text { will be useful for you? }\end{array}$} & $\begin{array}{l}\text { Professional and personal } \\
\text { development }\end{array}$ & 35 & 34 & 29 \\
\hline & Only professional development & 2 & 4 & 8 \\
\hline & Only personal development & 3 & 1 & 3 \\
\hline & $\begin{array}{l}\text { It will be no use in professional } \\
\text { and personal development. }\end{array}$ & 0 & 0 & 0 \\
\hline \multirow{2}{*}{$\begin{array}{l}\text { Do you want other courses } \\
\text { in the future to be designed } \\
\text { like this one? }\end{array}$} & Yes & 26 & 18 & 19 \\
\hline & No & 14 & 21 & 21 \\
\hline \multirow{2}{*}{$\begin{array}{l}\text { Would you recommend this } \\
\text { course to someone else? }\end{array}$} & Yes & 34 & 29 & 28 \\
\hline & No & 6 & 10 & 12 \\
\hline \multirow[t]{2}{*}{ Do you like this course? } & Yes & 31 & 28 & 18 \\
\hline & No & 9 & 11 & 22 \\
\hline
\end{tabular}

When the data in Table 19 was examined, 73\% (N=29) and 23\% (N=9) of the students in the flipped classroom expressed their perceptions of the tasks in the lessons as useful and partially useful, respectively. $85 \%(\mathrm{~N}=33)$ and $13 \%(\mathrm{~N}=5)$ of the students in the blended learning group indicated their perceptions of the tasks as useful and partially useful. $75 \%(\mathrm{~N}=30)$ and $15 \%(\mathrm{~N}=5)$ of the students in the traditional faceto-face learning method perceived the tasks as useful and partially useful, consecutively. One student in each group expressed the opinion that the tasks in the lesson were not useful to their learning.

The majority of the students (flipped classroom $(\mathrm{N}=39)$ ), blended learning model and traditional learning method $(\mathrm{N}=31))$ indicated that the assigned tasks in the lessons were generally very easy or moderately difficult.

All the students in the study thought that what they had learned in the course was useful. $88 \%$ of the students in the flipped classroom $(\mathrm{N}=35), 87 \%$ of the students in the blended learning model $(\mathrm{N}=35)$ and $73 \%$ of the students in the traditional model $(\mathrm{N}=29)$ stated that what they had learned in the course would be beneficial for their professional and personal development. None of the students in the study preferred the "it will be of no use in professional and personal development" answer with respect of the knowledge acquired on the course.

It was shown in Table 19 that the students in the Experimental group-I were more satisfied with the method implemented, asked for the other courses to be designed like this and advised others about this course. They liked the course better than the students in the Experimental group-II and control groups. According to these findings, the students' satisfaction levels in the Experimental group-I were higher than those in the other groups. So, it can be deduced that the students in the flipped classroom were more involved in active learning than the ones in the other groups.

The students in the flipped classroom were asked what their perceptions of the teaching videos were. The frequency of their answers is displayed in Table 20. 
Table 20. The perceptions of the experimental group-I with regard to the video contents and lengths

\begin{tabular}{llc}
\hline Variables & Values & F \\
\hline Video contents in general; & Very interesting & 26 \\
& Partly interesting & 6 \\
& Not interesting & 6 \\
& Indecisive & 2 \\
\hline Video lengths are about 15 minutes on average; & Too long for the content given & 2 \\
& Appropriate for given content & 36 \\
\hline
\end{tabular}

As seen from Table $20,80 \%$ of the students in the flipped classroom $(\mathrm{N}=32)$ found the video contents interesting, whereas $15 \%$ of them perceived them as not interesting. $5 \%$ of them $(\mathrm{N}=2)$ were indecisive about the content. On the other hand, $90 \%$ of the students $(\mathrm{N}=36)$ thought that the lengths of the videos were appropriate for the content. $5 \%$ of them $(\mathrm{N}=2)$ found the length of the videos long, whereas $5 \%$ of them $(\mathrm{N}=2)$ perceived them as too short.

\section{DISCUSSION, RESULTS AND SUGGESTIONS}

In this part, the results derived from the findings and interpretations in this research are provided. The results are discussed in the light of the literature review and the suggestions are made based on these results.

\section{The Results with regard to Academic Achievement}

In the aftermath of the implementation experiment, it was found that the majority of the students' posttest academic achievement scores in the control and experimental groups indicated statistically significant differences when their pre-test scores were controlled. This result reveals that these three different instruction methods, which were applied in this study, have different results on the students' achievement. When we consider which method is more effective, the flipped classroom is more effective in teaching and learning processes. The traditional face-to-face learning method has the lowest effect on the processes. The flipped classroom and the blended learning methods enhanced the students' academic achievements compared with the traditional face-to-face teaching method. In other words, it was derived from these results that the students in the Experiment-I and Experiment-II groups were more successful than the ones in the control group.

When the literature review with regard to the flipped classroom was examined, it was seen that the model increased achievement in a number of fields including mathematics, foreign languages, science, medicine and engineering (Boyraz, 2014; Ceylan, 2015; Sirakaya, 2015; Turan, 2015; Aydin, 2016; Bhagat et al., 2016; Foldnes, 2016; Gonza'lez-Go'mez et al., 2016; Saglam, 2016; AlJaser, 2017; Atwa, Din and Hussin, 2017; Cakir, 2017, Thai et al., 2017; Elian and Hamaidi, 2018; Iyitoglu, 2018). On the other hand, the studies indicated the model was not making a significant enhancement (Davies, Dean and Ball, 2013; Findlay and Mombourquette, 2014; Overmyer, 2014; Touchton, 2015; Duffy, 2016; Yavuz, 2016; Dixon, 2017). The reasons for these conflicting results obtained from the study can stem from the type and quality of the materials used in the model, the differences in the activities conducted during the class study time and the setting where the model was provided. Another reason for this difference could be that each instructor who conducts the model, could implement and plan the processes differently. The participants' engagement with the processes of the model, attitudes towards their courses and motivations can be effective to generate different results. It can be stated that the lessons designed according to the flipped classroom should be wellplanned. 
The flipped classroom model enables students to come to class prepared (Zappe et al., 2009; Halili and Zainuddin, 2015; Talan, 2018), provides a process which focuses on interactive and applied learning (Bosner et al., 2015), enhances the teacher-student interaction (Bergmann and Sams, 2012; Arshad and Imran, 2013; Bergmann, Overmyer and Wilie, 2013; Rutkowski and Moscinska, 2013; Kim et al., 2014; Halili and Zainuddin, 2015; Talan, 2018), presents immediate feedback (Milman, 2012; Arshad and Imran, 2013; McGivney-Burelle and Xue, 2013; McLaughlin et al., 2014) and offers teachers an opportunity to guide (Sirakaya, 2015). These characteristics of the model are the ones which increase students' achievements. The model supports individual self-paced learning (Bishop and Verleger, 2013), creates time to fulfil active learning activities (Bergmann and Sams, 2012), enables students to undertake their responsibilities to learn (Chen et al., 2014; Chu and Sun, 2015), ensures cooperation and question and answer and discussions (Street et al., 2015). Furthermore, this model makes long-lasting learning outcomes by offering rich and accessible materials (Mason et al., 2013; Turan and Goktas, 2015).

It was found that there was not a significant difference in the weekly quiz scores of the students in the control, Experimental -I and Experimental-II groups. As a result of the analysis, the students' scores in Experimental group-I $(=33.95)$, in Experimental-II $(=33.59)$ and in the control groups $(=30.45)$ were confirmed. The derived result from the current research shows consistencies with the results of the study conducted by Sirakaya (2015). The fact that a significant difference did not occur in the scores of the weekly quizzes of the students in the three different groups can be accounted for by the effective levels of questions asked in the quizzes (Sirakaya, 2015). The questions in the quizzes consisted of knowledge and comprehension questions. The students in the Experimental group-I learned the knowledge at a low level by watching videos, reading and tracking e-book notes (lesson notes) prior to their lessons, whereas the students in the Experimental group-II and the control group acquired the knowledge through the lectures in the class. The reason why the significant differences do not take place in the quiz scores of the students can be justified with this explanation. It is thought that e-book, videos and the lectures in classes ensure that they learn the knowledge at a low level.

\section{The Results with regard to Academic Engagement}

There is a significant difference in the academic engagement scores of the students in the control and experimental groups and this result is significant in favor of the Experiment-I and Experiment-II groups. As the students in the Experiment-I and Experiment-II groups are more involved in the academic engagement, compared to the control group, it was felt that the students in the Experiment-I and Experiment-II groups made more effort in the academic sense. Also, there was a significant difference in the student-teacher interaction and feedback dimensions among the students in the control and experimental groups. It was revealed that the students in the flipped classroom and the blended learning environment participate more in the lessons than those students in the traditional face-to-face learning environment in terms of the studentteacher dimension. With regard to feedback, it was indicated that the students in the blended learning environment participate more in the lessons than those students in the traditional face-to-face learning environment. This difference can be accounted for by the fact that the students in the flipped classroom and blended learning models interact more with their teachers and classmates and therefore get more feedback than the students in the traditional face-to-face learning method. A significant difference did not occur in the engagements in the course and its requirements, active learning and difficulties dimensions. According to this result, the students in these three different groups had common characteristics with regard to the above-mentioned dimensions.

The literature review confirms that the flipped classroom offers an active learning environment and increases students' participation (Bergmann and Sams, 2012; Brunsell and Horejsi, 2011; Tucker, 2012; Young, 2011; Clark, 2015; Gilboy, Heinerichs and Pazzaglia, 2015). In this regard, it has positive effects on their participation in their lessons.

When the results of the academic achievement tests and academic engagement scale of the students in the control and experimental groups were considered, it was seen that the relationship between their academic achievement scores and the academic engagement ones was moderately positive. It can be stated, based on this finding, that when academic achievement increases, academic engagement increases, too. The conducted research revealed that there was a significant relationship between academic achievement and academic 
engagement (Kong, Wong and Lam, 2003; Pike and Kuh, 2005; Kuh, 2009; Errey and Wood, 2011; Fredricks, 2011; Marzano, 2013; Harbouret al., 2015). In this study, the students in the Experiment-I and Experiment-II groups participated more in the lessons than the ones in the control group. The students in the flipped classroom and the blended learning models attended the lessons more in terms of feedback and teacher-student interaction dimensions and this was reflected in their academic achievement. These results can be because the students in the flipped learning and blended learning models, who used online learning, interacted with their teachers and students more and got more feedback than those in the traditional faceto-face learning environment, before and during out-of- the class study time.

\section{The Results with regard to the Satisfaction Levels}

According to the research results, all the students indicated that what they had learned in the lesson was useful to them. In addition, it was determined that the students in the flipped classroom were satisfied with the implementation method and they asked that the other lessons be designed like this lesson and would recommend the lesson to others. Other similar research results with regard to the flipped classroom are in parallel with this research (Davies, Dean and Ball, 2013; Pinto and Little,2014; Young et al., 2014; Asef-Vaziri, 2015; Gilboy, Heinerichs and Pazzaglia, 2015; Morgan et al., 2015; Street et al., 2015; Tan, Brainard and Larkin, 2015; Touchton, 2015). The most important reasons for this could be that the model offers active learning activities, effective use of time in the classroom, self-paced learning and enables them to watch videos whenever and wherever they want. However, some studies indicated that students were not satisfied with using this model (Missildine et al., 2013). Similarly, some studies revealed that there was no difference in the satisfaction of the students attending the flipped classroom and the other learning environments (Butzler, 2014; Whillier and Lystad, 2015).

When the current research results are evaluated within the general framework, the flipped classroom has positive effects on the students' academic achievements and engagements. They are more involved in academic engagement and generally satisfied with this model.

\section{SUGGESTIONS}

The following research suggestions can be made to contribute to developing the flipped classroom and to shedding light on new studies based on the current research results:

1. The current research included the pre-service teachers at the level of higher education. Similar studies could be conducted with different participants at other educational levels to reach a general result and make comparisons.

2. In this research, the academic achievements and engagements of the students in different teaching approaches were compared. Descriptive and experimental studies could be conducted to search the relationship between self-regulation, perceived self-efficacy, motivation, exam anxieties and attitudes with regard to academic achievements and academic engagements in these approaches in different studies. In future studies, the effectiveness of these methods could be tested in detail by using these variables.

3. Different instruction methods, including cooperative learning, problem based learning, project based learning and mobile learning could be blended with the flipped classroom and the effectiveness of these methods could be tested.

4. The effects of the preparation periods prior to the class study time and lengths of videos could be investigated.

5. Training programs could be applied in the flipped classroom in one semester or academic year to reveal its far-reaching effects. Long periods can be important to observe changes in variables, particularly "academic achievement".

6. In addition to observations, individual interviews or focus group interviews in the flipped classroom, data could be analyzed using mixed research methods. In this way, a broader perspective could be attained to understand the perceived effects of increasing students' participation in the flipped classroom. 


\section{BIODATA and CONTACT ADDRESSES of AUTHORS}

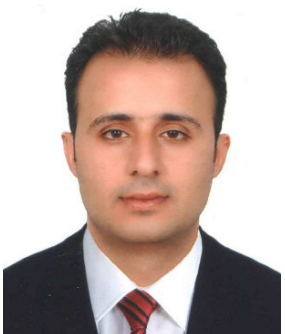

Dr. Tarik TALAN, is a lecturer at Kilis 7 Aralik University, Turkey. He has received the BSc degree in Department of Computer Education and Instructional Technology from Inonu University in 2005; MSc degree in Educational Technology from Suleyman Demirel University in 2014 and PhD degree from Istanbul University Informatics Department in 2018. His research areas include blended learning, distance learning, human-computer interaction and use of social media in education. He has published his academic works in national and international journals.

Tarik TALAN

Vocational School of Technical Sciences, Kilis 7 Aralik University

Adress: Mehmet Sanli Mah. Dogan Gures Pasa Bul. No:134, 79000, Kilis, TURKEY

Phone: + 093488142666

e-mail: ttalan46@hotmail.com

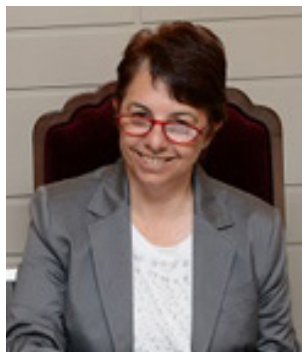

Dr. Sevinc GULSECEN, is a Professor and Head of Informatics Department at Istanbul University, Istanbul, Turkey. Dr. Gulsecen had her doctoral degree in MIS from Faculty of Business, Istanbul University. Dr. Gulsecen has her primary teaching and research interest in system analysis and design, constructivist learning, e-learning, computer-mediated communication, community and social informatics, and KM. Dr. Gulsecen has published her research in several national and international journals, conference proceedings and edited books such as International Journal of E-adoption, IEEE Technology and Society, Educational Technology and Society, Turkish Journal on Education and Research, Digital Learning Environments and Student Centered Curriculum in a University Context.

\section{Sevinc GULSECEN}

Department of Informatics, Istanbul University

Adress: Kalenderhane Mah. Bozdogan Kemeri Cad. No:13 PK 34134 Vezneciler-Beyazit-Fatih/Istanbul, TURKEY

Phone: +902124400042

e-mail: sevincg@yahoo.com

\section{REFERENCES}

Abeysekera, L., \& Dawson, P. (2015). Motivation and cognitive load in the flipped classroom: definition, rationale and a call for research. Higher Education Research \& Development, 34(1), 1-14.

Akbulut, E. (2010). Levels of the empathic tendencies of classroom teachers. [Sinif Ogretmenlerinin Empatik Egilim Duzeyleri.] Unpublished Master Thesis. [Yayinlanmamis Yuksek Lisans Tezi.] Sakarya University. [Sakarya Universitesi.]

AlJaser, A. M. (2017). Effectiveness of Using Flipped Classroom Strategy in Academic Achievement and Self-Efficacy among Education Students of Princess Nourah bint Abdulrahman University. English Language Teaching, 10(4), 67.

Arshad, K., \& Imran, M. A. (2013). Increasing the interaction time in a lecture by integrating flipped classroom and just-in-time teaching concepts. Compass: Journal of Learning and Teaching, 4(7).

Ary, D., Jacobs, L.C., Sorensen, C.K., \& Razavieh, A. (2010). Introduction to research in education (8th ed.). Belmont, CA: Wadsworth, Cengage Learning.

Asef-Vaziri, A. (2015). The Flipped Classroom of Operations Management: A Not-For-Cost-Reduction Platform. Decision Sciences Journal of Innovative Education, 13(1), 71-89.

Astin, A. W. (1984). Student involvement: A developmental theory for higher education. Journal of College Student Personnel, 25, 297-307. 
Atwa, Z. M., Din, R., \& Hussin, M. (2017). Effectiveness of Flipped Learning in Physics Education on Palestinian High School Students' Achievement. Journal of Personalized Learning, 2(1), 73-85.

Aydin, B. (2016). The effects of flipped classroom model on academic achievement, homework/task stress level and transfer of learning. [Ters Yuz Sinif Modelinin Akademik Basari, Odev/Gorev Stres Duzeyi ve Ogrenme Transferi Uzerindeki Etkisi.] Unpublished Master Thesis. [Yayinlanmamis Yuksek Lisans Tezi.] Suleyman Demirel University. [Suleyman Demirel Universitesi.]

Baker, J. (2000). The 'classroom flip': Using web course management tools to become the guide by the side. 11 th international conference on College Teaching and Learning, Jacksonville, FL.

Bergmann, J. , \& Sams, A. (2012). Flip your classroom: Reach every student in every class every day. Washington: International Society for Technology in Education.

Bergmann, J., Overmyer, J., \& Wilie, B. (2013). The flipped class: What it is and what it is not. The Daily Riff, 9.

Bhagat, K. K., Chang, C. N. , \& Chang, C. Y. (2016). The impact of the flipped classroom on mathematics concept learning in high school. Educational Technology \& Society, 19(3), 134-142.

Bishop, J. L., \& Verleger, M. A. (2013). The flipped classroom: A survey of the research. In ASEE National Conference Proceedings, Atlanta, GA, 30(9), 1-18.

Boyraz, S. (2014). Evaluating flipped classroom/education method in English teaching. [Ingilizce Ogretiminde Tersine Egitim Uygulamasinin Degerlendirilmesi.] Unpublished Master Thesis. [Yayinlanmamis Yuksek Lisans Tezi.] Afyon Kocatepe University. [Afyon Kocatepe Universitesi.]

Bosner, S., Pickert, J., \& Stibane, T. (2015). Teaching differential diagnosis in primary care using an inverted classroom approach: student satisfaction and gain in skills and knowledge. BMC medical education, 15(1), 63.

Brunsell, E., \& Horejsi, M. (2011). Flipping your classroom. Learning and Leading with Technology, 78(2), 10.

Butzler, K. B. (2014). The effects of motivation on achievement and satisfaction in a flipped classroom learning environment. Northcentral University.

Buyukozturk, S.(2011) Sosyal Bilimler icin Veri Analizi El Kitabi. Pegem Akademi Publications, Ankara.

Can, A. (2013). SPSS ile Bilimsel Arastirma Surecinde Nicel Veri Analizi. Pegem Publications, Ankara.

Ceylan, C. K. (2015). Effect of blended learning to academic achievement. [Harmanlanmis Ogrenme Yonteminin Akademik Basariya Etkisi.] Unpublished Master Thesis. [Yayinlanmamis Yuksek Lisans Tezi.] Adnan Menderes University. [Adnan Menderes Universitesi.]

Chapman, E. (2003). Assessing student engagement rates. ERIC Digest.

Chen, Y., Wang, Y., \& Chen, N. S. (2014). Is FLIP enough? Or should we use the FLIPPED model instead?. Computers \& Education, 79, 16-27.

Chu, L., \& Sun, S. H. (2015). The application of flipped classroom in pediatric physical therapy. Physiotherapy, 101, e252.

Clark, K. R. (2015). The effects of the flipped model of instruction on student engagement and performance in the secondary mathematics classroom. Journal of Educators Online, 12(1), 91-115.

Creswell, J., W. (2012). Educational research: Planning, conducting, and evaluating quantitative and qualitative research (4th ed). Upper Saddle River, NJ: Merrill.

Cakir, E. (2017). The effect of flipped classroom on 7th grade students' academic achievement, cognitive risk taking skills and computational thinking skills in science education classroom. [Ters yuz sinif uygulamalarinin fen bilimleri 7. sinif ogrencilerinin akademik basari, zihinsel risk alma ve bilgisayarca dusunme becerileri uzerine etkisi.] Unpublished Master Thesis. [Yayinlanmamis Yuksek Lisans Tezi.] Ondokuz Mayis University. [Ondokuz Mayis Universitesi.] 
Dabbagh, N., \& Bannan-Ritland, B. (2005). Online learning: Concepts, strategies, and application. Prentice Hall.

Davies, R. S., Dean, D. L., \& Ball, N. (2013). Flipping the classroom and instructional technology integration in a college-level information systems spreadsheet course. Educational Technology Research and Development, 61(4), 563-580.

Demiralay, R. (2014). Examining the process of flipped classroom model acceptance in the context of diffusion of innovations theory. [Evde Ders Okulda Odev Modelinin Benimsenmesi Surecinin Yeniligin Yayilimi Kurami Cercevesinde Incelenmesi.] Unpublished Doctoral Dissertation. [Yayinlanmamis Doktora Tezi.] Gazi University. [Gazi Universitesi.]

Dixon, K. L. (2017). The effect of the flipped classroom on urban high school students' motivation and academic achievement in a high school science course. Liberty University.

Driscoll, M. (2002). Blended learning: Let's get beyond the hype. E-learning, 1(4), 1-4.

Duffy, C. M. (2016). The impact of flipped learning on student achievement in an eighth grade earth science classroom. Doctoral Dissertation, Wilkes University.

Elian, S. M., \& Hamaidi, D. A. H., (2018). The Effect of Using Flipped Classroom Strategy on the Academic Achievement of Fourth Grade Students in Jordan, International Journal of Emerging Technologies in Learning (iJET), 13(02), 110-125.

Errey, R., \& Wood, G. (2011). Lessons from a student engagement pilot study. Australian Universities' Review, 53(1), 21-34.

Findlay-Thompson, S., \& Mombourquette, P. (2014). Evaluation of a flipped classroom in an undergraduate business course. Business Education \& Accreditation, 6(1), 63-72.

Foldnes, N. (2016). The flipped classroom and cooperative learning: Evidence from a randomised experiment. Active Learning in Higher Education, 17(1), 39-49.

Fredricks, J. A. (2011). Engagement in school and out-of-school contexts: A multidimensional view of engagement. Theory Into Practice, 50, 327-335.

Furrer, C., \& Skinner, E. (2003). Sense of relatedness as a factor in children's academic engagement and performance. Journal of educational psychology, 95(1), 148.

Gilboy, M. B., Heinerichs, S., \& Pazzaglia, G. (2015). Enhancing student engagement using the flipped classroom. Journal of Nutrition Education and Behavior, 47(1), 109-114. doi:10.1016/j. jneb.2014.08.008

Gonzalez-Gomez, D., Jeong, J. S., \& Rodriguez, D. A. (2016). Performance and perception in the flipped learning model: an initial approach to evaluate the effectiveness of a new teaching methodology in a general science classroom. Journal of Science Education and Technology, 25(3), 450-459.

Halili,S. H., \& Zainuddin, Z. (2015). Flipping the classroom: what we know and what we do not. The Online Journal of Distance Education and e-Learning (TOJDEL), 3(1), 28-35.

Harbour, K. E., Evanovich, L. L., Sweigart, C. A., \& Hughes, L. E. (2015). A brief review of effective teaching practices that maximize student engagement. Preventing School Failure, 59(1), 5-13.

Horton, W. (2011). E-learning by design. John Wiley \& Sons.

Iyitoglu, O. (2018). The impact of flipped classroom model on EFL learners' academic achievement, attitudes and self-efficacy beliefs: a mixed method study. Doctoral Dissertation. Yildiz Teknik University.

Johnson, D. (2012). Power up!: Taking charge of online learning. Educational Leadership, 70(3), 84-85.

Kalayci, S. (2010). SPSS Uygulamali Cok Degiskenli Istatistik Teknikleri. Asil Publications, Ankara.

Kim, M. K., Kim, S. M., Khera, O., \& Getman, J. (2014). The experience of three flipped classrooms in an urban university: an exploration of design principles. The Internet and Higher Education, 22, $37-50$. 
Kim, S. H., Park, N. H., \& Joo, K. H. (2014). Effects of flipped classroom based on smart learning on selfdirected and collaborative learning. International journal of control and automation, 7(12), 69-80.

Kong, Q. P., Wong, N. Y., \& Lam, C. C. (2003). Student engagement in mathematics: Development of instrument and validation of construct. Mathematics Education Research Journal, 15(1), 4-21.

Korucu, A. T. (2013). In the environment of problem-based collaborative learning the effect of dynamic web technologies on academic achievement and academic engagement. [Problem temelli isbirlikli ogrenme ortaminda dinamik web teknolojilerinin akademik basari ile akademik ugrasiya etkisi.] Unpublished Doctoral Dissertation. [Yayinlanmamis Doktora Tezi.] Gazi University. [Gazi Universitesi.]

Kuh, G. D. (2008). High impact education practices: What they are, who has access to them and why they matter. Washington DC: Association of American Colleges and Universities.

Kuh, G. D. (2009). The National Survey of Student Engagement: Conceptual and empirical foundations. New Directions for Institutional Research, 2009(141), 5-20.

Kuh, G. D., Kinzie, J., Buckley, J. A., Bridges, B. K., \& Hayek, J. C. (2011). Piecing together the student success puzzle: Research, propositions, and recommendations: ASHE higher education report. San Francisco: John Wiley \& Sons.

Marzano, R. (2013). Art and science of teaching/ask yourself: Are students engaged. ASCD: Technology-Rich.

Mason, G. S., Shuman T. R., \& Cook, K. E. (2013). Comparing the effectiveness of an inverted classroom to a traditional classroom in an upper-division engineering course, IEEE Transactions on Education, 56(4).

McGivney-Burelle, J., \& Xue, F. (2013). Flipping calculus. PRIMUS: Problems, Resources, and Issues in Mathematics Undergraduate Studies, 23(5), 477-486.

McLaughlin, J. E., Gharkholonarehe, N., \& Esserman, D. A. (2014). The flipped classroom: a course redesign to foster learning and engagement in a health professions school. Academic Medicine, $8(2)$.

Mertler, C. A., \& Vannatta, R. A. (2002). A guide to multivariate techniques. Advanced and Multivariate Statistical Methods. 2nd ed. Los Angeles, CA: Pyrczak Publishing.

Milman, N. B. (2012). The flipped classroom strategy: What is it and how can it best be used?. Distance Learning, 9(3), 85.

Missildine, K., Fountain, R., Summers, L., \& Gosselin, K. (2013). Flipping the classroom to improve student performance and satisfaction. Journal of Nursing Education, 52(10), 597-599.

Morgan, H., McLean, K., Chapman, C., Fitzgerald, J., Yousuf, A., \& Hammoud, M. (2015). The flipped classroom for medical students. The clinical teacher, 12(3), 155-160.

O'Flaherty, J., \& Phillips, C. (2015). The use of flipped classrooms in higher education: a scoping review. The Internet and Higher Education, 25, 85-95.

Osguthorpe, R. T., \& Graham, C. R. (2003). Blended learning systems: Definitions and Directions. Quarterly Review of Distance Education, 4(3), 227-234.

Overmyer, G. R. (2014). The Flipped Classroom for college algebra: Effects on student achievement. Doctoral Dissertation. Colorado State University.

Pascarella, E. T., \& Terenzini, P. T. (1991). How College Affects Students: Findings and Insights from Twenty Years of Research. San Francisco, CA: Jossey-Bass.

Pike, G. R. \& Kuh, G. D. (2005). A typology of student engagement for American colleges and universities. Research in Higher Education, 46, 185-209.

Pinto, C., \& Little, G. (2014). Flipped librarians: Assessing our own need to understand our users. The Journal of academic librarianship, 2(40), 192-193. Research. 120th ASEE Annual Conference \& Exposition. Atlanta: GA. 
Robson, C. (2011). Real world research (3th ed.). West Sussex, England: Wiley.

Rutkowski, J., \& Moscinska, K. (2013, September). Self-directed learning and flip teaching: electric circuit theory case study. 41st SEFI Conference, Leuven, Belgium.

Saglam, D (2016). The effect of flipped classroom model on the academic achievements and attitudes of students in English language teaching. [Ters-Yuz Sinif Modelinin Ingilizce Dersinde Ogrencilerin Akademik Basarilarina ve Tutumlarina Etkisi.] Unpublished Master Thesis. [Yayinlanmamis Yuksek Lisans Tezi.] Bulent Ecevit University. [Bulent Ecevit Universitesi.]

Sirakaya, D. A. (2015). The effect of flipped classroom model on academic achievement, self - directed learning readiness and motivation. [Tersyuz Sinif Modelinin Akademik Basari, Oz-Yonetimli Ogrenme Hazirbulunuslugu ve Motivasyon Uzerine Etkisi.] Unpublished Doctoral Dissertation. [Yayinlanmamis Doktora Tezi.] Gazi University. [Gazi Universitesi.]

Singh, H., \& Reed, C. (2002). Achieving Success with Blended Learning, Centra White Paper.

Skinner, E. A., Kinderman, T. A., \& Furrer, C. J. (2009). A motivational perspective on engagement and disaffection: Conceptualization and assessment of children's behavioral and emotional participation in academic activities in the classroom. Educational and Psychological Measurement, 69, 493-525.

Strayer, J. F. (2012). How learning in an inverted classroom influences cooperation, innovation, and task orientation. Learning Environment Research, 15, 171-193.

Street, S. E., Gilliland, K. O., McNeil, C., \& Royal, K. (2015). The flipped classroom improved medical student performance and satisfaction in a pre-clinical physiology course. Medical Science Educator, 25(1), 35-43.

Talan, T. (2018). Design of E-Learning Environment According to Flipped Classroom Model and Evaluation of Model Applicability. [Donusturulmus Sinif Modeline Gore E-Ogrenme Ortaminin Tasarimi ve Modelin Uygulanabilirliginin Degerlendirilmesi.] Unpublished Doctoral Dissertation. [Yayinlanmamis Doktora Tezi.] Istanbul University. [Istanbul Universitesi.]

Tan, E., Brainard, A., \& Larkin, G. L. (2015). Acceptability of the flipped classroom approach for in-house teaching in emergency medicine. Emergency Medicine Australasia, 27(5), 453-459.

Thai, T. N., De Wever, B., \& Valcke, M. (2017). The impact of a flipped classroom design on learning performance in higher education: Looking for the best "blend" of lectures and guiding questions with feedback. Computers \& Education. 107, 113-126.

Touchton, M. (2015). Flipping the classroom and student performance in advanced statistics: Evidence from a quasi-experiment. Journal of Political Science Education, 11(1), 28-44.

Tucker, B. (2012). The flipped classroom. Education next, 12(1).

Turan, Z.(2015). The evaluation of flipped classroom method and examination of its effects on academic achievement, cognitive load and motivation. [Ters yuz sinif yonteminin degerlendirilmesi ve akademik basari, bilissel yuk ve motivasyona etkisinin incelenmesi]. Unpublished Doctoral Dissertation. [Yayinlanmamis Doktora Tezi.] Ataturk University. [Ataturk Universitesi.]

Turan, Z., \& Goktas, Y. (2015). A New Approach in Higher Education: The Students' Views on Flipped Classroom Method. [Yuksekogretimde Yeni Bir Yaklasim: Ogrencilerin Ters Yuz Sinif Yontemine Iliskin Gorusleri.] Journal of Higher Education \& Science/Yuksekogretim ve Bilim Dergisi, 5(2).

Umbach, P. D., \& Wawrzynski, M. R. (2005). Faculty do matter: The role of college faculty in student learning and engagement. Research in Higher Education 46 (2), 153-184.

Wang, Z., Bergin, C., \& Bergin, D. A. (2014). Measuring engagement in fourth to twelfth grade classrooms: The classroom engagement inventory. School Psychology Quarterly: The Official Journal of the Division of School Psychology, American Psychological Association, 29(4), 517-35.

Whillier, S., \& Lystad, R. P. (2015). No differences in grades or level of satisfaction in a flipped classroom for neuroanatomy. Journal of Chiropractic Education, 29(2), 127-133. 
Yavuz, M. (2016). An investigation into the effects of flipped classroom applications on the academic success and experiences of the students at secondary school. [Ortaogretim Duzeyinde Ters Yuz Sinif Uygulamalarinin Akademik Basari Uzerine Etkisi ve Ogrenci Deneyimlerinin Incelenmesi.] Unpublished Master Thesis. [Yayinlanmamis Yuksek Lisans Tezi.] Ataturk University. [Ataturk Universitesi.]

Young, E. (2011). Flip it: An interview with Aaron Sams and Jonathan Bergmann. Go Teach, 1(1), 12-14.

Young, T. P., Bailey, C. J., Guptill, M., Thorp, A. W., \& Thomas, T. L. (2014). The flipped classroom: a modality for mixed asynchronous and synchronous learning in a residency program. Western Journal of Emergency Medicine, 15(7), 938.

Zappe, S. Leicht, R., Messner, J., Litzinger, T., \& Lee, H. W. (2009). Flipping the classroom to explore active learning in a large undergraduate course. ASEE Conference, Austin, TX. 